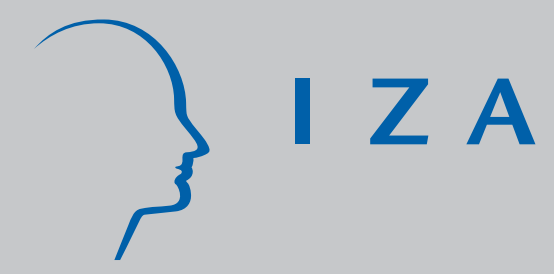

IZA DP No. 1578

Measurement of Globalization and Its Variations Among Countries, Regions and Over Time

Amit K. Bhandari

Almas Heshmati

April 2005 


\title{
Measurement of Globalization and Its Variations Among Countries, Regions and Over Time
}

\author{
Amit K. Bhandari \\ University of Kalyani \\ Almas Heshmati \\ MTT Economic Research, Seoul National University \\ and IZA Bonn
}

Discussion Paper No. 1578

April 2005

IZA

P.O. Box 7240

53072 Bonn

Germany

Phone: +49-228-3894-0

Fax: +49-228-3894-180

Email: iza@iza.org

\begin{abstract}
Any opinions expressed here are those of the author(s) and not those of the institute. Research disseminated by IZA may include views on policy, but the institute itself takes no institutional policy positions.

The Institute for the Study of Labor (IZA) in Bonn is a local and virtual international research center and a place of communication between science, politics and business. IZA is an independent nonprofit company supported by Deutsche Post World Net. The center is associated with the University of Bonn and offers a stimulating research environment through its research networks, research support, and visitors and doctoral programs. IZA engages in (i) original and internationally competitive research in all fields of labor economics, (ii) development of policy concepts, and (iii) dissemination of research results and concepts to the interested public.
\end{abstract}

IZA Discussion Papers often represent preliminary work and are circulated to encourage discussion. Citation of such a paper should account for its provisional character. A revised version may be available directly from the author. 


\section{ABSTRACT}

\section{Measurement of Globalization and Its Variations Among Countries, Regions and Over Time}

The process of globalization is an international economic order which has led to the progressive integration of the world economy through the pulling the barrier of trade and greater mobility of factors of production. In addition the technological innovation also provides impetus to the progressive integration of the nations. The elements of globalization include free movement of goods and services, flow of capital, movement of labor and the transfer of technology. Many transition and developing countries through liberalization and increased openness to trade have benefited from the process. Apart from the economic benefits, globalization also indicates the flow of ideas, norms, information and peoples. There is a large heterogeneity in the degree of globalization over time and across countries and regions of the World, as well as within countries. The present study is an attempt to measure globalization by using both parametric and non-parametric approaches. The data cover a wide range of industrialized, transition and developing countries on the basis of their international integration. We identify the factors influencing globalization among the countries in the form of economic integration, personal contact, technology and political engagement. We isolate the contribution of the factors by quantifying the individual factor contribution to the overall integration. Finally, we investigate the links between globalization and labor market in India manufacturing industry.

JEL Classification: $\quad$ C43, F15, L60, O50

Keywords: globalization, economic integration, composite index, manufacturing, India

Corresponding author:

Almas Heshmati

TEPP, College of Engineering

Seoul National University

Bldg \#38, Room 410

San 56-1, Shilin-dong, Kwanak-gu

Seoul 151-742

Korea

Email: heshmati@snu.ac.kr 


\section{INTRODUCTION}

The proper meaning of globalization is a debatable issue. The meaning of globalization can be different to different people and different disciplines. We are not going for elaborating this debate. In general globalization is a process in which the combined force of different elements leading to an increase in countries dependence on or from more positive point of view of interactions with the rest of the world. The process of globalization is an international economic order which lead to the progressive integration of the world economy through pulling the barrier of trade, exchange rate and greater mobility of factors of production. The reduction of impediments in the movements of goods and factors of production may possibly enhance allocative efficiency both in global and national economies. The technological innovation especially in communication also provides impetus to the progressive integration of the nations by pushing aside all geographical barriers. Now the debate remains whether globalization is driven by the market and technology or is it the result of conscious decisions of the countries.

Globalization is the process of formation of global market in products as well as in factors of production. The elements of globalization include free movement of goods and services, flow of capital, movement of labor and the transfer of technology which has brought the developed economies closer together and made them more strongly integrated. Many transition and developing countries through liberalization and increased openness to trade have benefited from the process. Globalization is much more than simply the growth, expansion of international trade and the movements of factors of production. It could be thought as the extent and legitimate fabric of a highly diverse world. (see Rowntree et al, 2000) Although economic interconnectedness is the prime mover of globalization, the conflicting behaviour of environment, culture, political and social development antecedes contemporary development process. Apart from that globalization also indicates the flow of ideas, norms, informations and peoples.

The experiences with globalization in different part of the world are different. There is a large heterogeneity in the degree of globalization over time and across countries and economic and geographic regions of the World, as well as regions within countries. Geographic diversities across the world arise as a conflict with globalization. As a result, unevenness in the economic landscape is the stark reality of the present world. Some places in the world thrives, other suffer from unrelenting impoverishment. Even within country gap between rich and poor has been broadening. Economic change also sparks the cultural transformation. The forces of homogeneous global culture attempt to spread across countries. Moreover, the global political environment rapidly changing its semblance following the collapse of Soviet Union contributed much to the progressive integration of the world economy. However, country has no option to remain isolated from the rest of the world otherwise have to pay high price of that. Although there is a mismatch between cost and benefits where the cost are easily identifiable and the benefits are often delayed, occur over a longer period of time. ${ }^{1}$

Contemporary discussion on the economic integration of nations is dominated by financial globalization. Historically this is not a new phenomenon which has its roots

\footnotetext{
${ }^{1}$ See Tanzi (2004), Stiglitz (2002).
} 
long back. (see Obstfeld and Taylor (1998), Baldwin and Martin (1999), Collins and Williamson (1999)). By that time only few countries participated in this process. The first setback was received in the form of Great Depression just after the First World War and the beginning of Second World War and continued for a couple of decades till 1960s. 1970s was marked by the new era of financial globalization with the break up of the Breton Wood System and the oil shock. The oil shock provided international banks with fresh funds to invest in developing countries. These funds were used mainly to finance public debt in the form of syndicated loans. This incidence was the clear manifestation of the opening up of financial system to the developing countries. During the last decade investment boom in the form of foreign direct investment (FDI) and portfolio flows to emerging markets got deeper with deregulation, privatization and technological renovation.

The financial aspect of globalization dominates entirely the discussion of globalization whereas little attention is being paid on the global movement of labor. Historically, the labor flows were associated with international migration occurred mainly in the form of slaves, emigrants, refugees, invaders and conquerors. In the present world, the new form of labor flows are being taking place in the form of guest workers, illegal immigrants and professionals are largely associated with the process of globalization and its associated development. ${ }^{2}$ The spread of globalization and its congregating momentum during the last quarter of $20^{\text {th }}$ century have not reflecting in the cross border movement of labor. The dominant concept of globalization is based on the belief that liberalization of trade and capital flows is deputized for labor flows. But the requirements of economic efficiency are not movement of capital but the movements of different types of labors are equally important. National boundaries are not only for trade and capital flows but there should also be clear dividing line for labor flows. Both developed and developing courtiers are benefited from the mobility of labor and income of migrant labors.

There are vast amount of empirical literatures discussing on various aspects of the recent wave of globalization is developing countries. Several special issues on globalization have been published in Oxford Development Studies, Journal of WorldSystems Research and the Journal of African Economies. Editorial introductions to these special issues are provided by Woods (1998); Manning (1999); Bata and Bergesen (2002a, 2002b); and Bevan and Fosu (2003). In addition, a number of books on the issue have been published. Dollar and Collier (2001) and the World Bank (2002) explore the relationship between globalization, growth and poverty; James (2002) analyses technology, globalization and poverty, Aghion and Williamson (1998) examine the relationship between globalization, growth and inequality, while Khan and Riskin (2001), focusing on history and policies, limit their study to the development in China. O'Rourke and Williamson (2000) look at the evolution of the 19th century Atlantic economy, and Tausch and Herrmann (2002) analyze globalization and European integration.

It is widely believed that in the current phase of globalization tends to reduce the degree of effective autonomy for national governments to pursue their own goals of growth, stability and social equity. At present, it is more costly to remain isolate itself from the rest of the world. Countries that are well educated, that are not excessively

${ }^{2}$ for more detail discussion see Nayyar (2002) 
bound by strong traditions or by past policies and that have more even income distributions and more ethnically homogeneous populations will be able to benefit more quickly from globalization and the benefits will be more widely diffused. (Tanzi, 2004). Government must play its fundamental role to help the country to adjust into the process of globalization.

Empirically, it has been observed that a smooth adjustment to the process of globalization forbade via three different routes - physical infrastructure, institutional infrastructure, or wrong policies, that government should come to the rescue. A well functioning infrastructure can only be provided by the initiatives of government. Free movement of products and factors ensures economic efficient in the production process. A quality infrastructure is necessary for a countries new economic environment which is inductive to a country's trade. Thus, a countries globalization process is closely linked with its existing physical infrastructure. For instance, developing countries like India facing major bottleneck in uncertain trade growth because of its failure to brought infrastructure to an international standard.

In addition to the physical infrastructure a countries economic activity largely depends on its institutional setup. Like a poor education system leads to poorly trained workers, in a failed judicial system it is more difficult to implement proper rules and regulations. All these deficiencies often lead to damaging international competitiveness. The failure in one institution is seriously inflicted on the functioning of other institutions in a chain. In a corrupt institutional system, different segments are not capable to adapt to the changing environments. For example, in South East Asian countries the economic crisis in 1997-98 is responsible due to the lack of correlation between economic growth and institutional advancement. So the urgent role of the government is to provide adequate institutional infrastructure by replacing traditional way of doing things and establish more transparent rules that can be applied to all economic and social spheres. But the political and social compulsion would often become the constraining factor to carry out these reforms.

It is to be noted that a good physical and institutional infrastructure does not always cater to the challenges of globalization but also a suitable policy orientation required for competing in the internationally competitive environment. Countries those opted for suitable policies benefited lot than in the past. The performances of China, South Korea, Taiwan, Ireland and other countries also corroborate the reality. Government should increase public spending by applying effective fiscal reform to cope with the shocks arising out of globalization. To strengthen the safety net of their citizen government may need to step in with the programs like retirement benefits, compensation to the unemployment, programs to start subsidizing loans to start other activities and so forth. These programs may costly and led to higher public spending.

The present study attempts to investigate the measurement of different approaches of globalization based on Kearney and principal component analysis covering wide range of industrialized, transition and developing countries on the basis of their international integration. We identified the factors influencing globalization among the countries in the form of economic integration, personal contact, technology and political engagement. The present study attempts to determine the contribution of the factors by quantifying the individual factor contribution to the overall integration and its variations in different dimensions. Currently, there is lack of data and standards to measure globalization. The study is an attempt to fill the gap in the literature. It is an attempt to analyze the very 
diverse aspects of globalization and subsequently the different channels through which it can have effects is a significant contribution to the existing literature. Finally, we investigate the links between globalization and labor market in India with focus on the manufacturing industry.

This chapter is organized as follows. In the next section we discuss globalization and trade and review the various effects of globalization and in particular those on the poor. In Section 3 and 4 we describe the data used in computation of the globalization indices and discuss distribution of the indicators. The methods of computation of the globalization index are presented in Section 5. Here two alternative parametric and non-parametric approaches are used to compute globalization index and decompose it into economic, technology, personal and political sub-components. In section 6 the relationship between the four different components is investigated. In section 7 the empirical results are discussed. The focus is on variation in degree of globalization across countries, geographic and economic regions, as well as over time. In section 8, attempt is made to link the globalization to the labor market in Indian manufacturing. The final section 9 concludes and provides policy measures and also suggestions for future advances in research on globalization.

\section{GLOBALIZATION}

Globalization is not a new phenomenon. It has its roots during the period of Industrial Revolution in 1789. Industrialization is normally portrayed as an example of European and British exceptionalism. O'Rourke and Williamson (2000), O'Rourke (2001), Maddison (2001) and Williamson (2002) identifies the period of globalization (18702000) into four distinct phases: the first wave of globalization 1870-1913, the deglobalization period of 1913-1950, the golden age of 1950-1973 and the second wave of globalization of 1973 onward.

Broadly the four decades of globalization up to the First World War was characterized by a phenomenon which largely driven by strong growth of trade and intercontinental financial and migratory flows. Those periods were dominated by European colonialism by their proficiency in innovative transportation and communications. The role of technology has massive capacity to generate huge profits which played crucial role in rapid interconnectiveness of human society. But societies which benefited most from the industrialization were in the race of earlier version of globalization. The next wave of globalization started after the Second World War when United States had emerged as the uncontested leader of the capitalist world.

In the first wave of globalization, the dismantling of mercantilism and the world-wide transport revolution worked together to produce truly global markets. That was a long period where the flow of factors was limited and the trade was dominated by few European investors. They believes in the strong growth prospect of oversees markets. It was collapsed into the world war. Instead of adopting mechanisms of global cooperation and development this period was marked by nationalism and the creation of national empires. So in the second phase inward looking policies were dominated almost all industrial nations aggravated by the second round of world war. The third wave of globalization was marked as the period of decolonization and saw the creation of multilateral institutions which managed to liberalization of trade and prevent return 
of national economic cooperation. But the colonialism left most independent countries poorly equipped to survive in the globalized world.

The current wave of globalization has been driven by the new set of factors, such as, deregulation of financial services, emergence of modern transportation and communication technologies, collapse of Eastern Bloc and demonstration of the success stories of the East Asian economies. During this golden age of globalization an onwards transnational capitalism becomes more active and strap up the third generation of technological change to build up global production network. They were lured by the profit and exploited the vulnerabilities in the Third world countries. The recent wave of globalization has been in the field of financial globalization influenced by the competitive deregulation of financial markets and the new revolution of information technology. The rapid integration of financial markets and the emergence of several new instruments of financial flows and financial management also propelled this process. The second wave of globalization was marked by the creation of wealthier, more educated and longer living populations who are able to connect the world in a new ways.

\subsection{Globalization, Trade and Development}

The importance of trade and foreign direct investment are most significant manifestation of globalization and economic development enhancing factors. The liberalization of trade constitutes the prime component of economic dimension of globalization which is highly significant during the total phase of globalization. Trade liberalization came first during the so called golden age (1950-73) of globalization with the unprecedented expansion of international trade. After Second World War, on an average trade has grown at roughly double the rate of growth of GDP. The growth in trade is connected with the internationalization of trade in manufacturing corporations. As a result, attracting FDI of the corporations assumes a special significance for improving the performance of the nations. This development is coincided with the upsurge in international investment begun in the late 1960s.

The pattern of world trade had undergone major changes during the current phase of globalization. The drastic reduction in barrier to international trade has opened the door for export led growth. Manufactures, which was a mere 20 per cent of total exports from the developing countries in the 1970s went up to 70 per cent in the 1990s. The share of minerals and oil exports was in the downward direction too. At the same time, the share of developed countries in world income (in current dollars) increased from less than 73 per cent in 1980 to 77 per cent in 1999, while that of the developing countries remained at a constant figure of 20 per cent. From the developing countries perspective there is a change in pattern that emerged during the 1980s and 1990s namely there was concentration of exports in the hands of a few East Asian countries in the developing world and the terms of trade of manufactures might have moved against the developing countries.

Little evidences are available on the contribution of FDI on the development of a countries economy. The most important thing to the global investor is the development of local infrastructure, which is crucially absent for most of the developing countries. Two unfavorable comparisons emerge between India and China on account of the role 
of FDI. In 1990s, almost after two decades of liberalization China started getting the benefits of FDI for their economic development. But in China, domestic investment as a share of national income is estimated as 40 per cent of GDP whereas in India it is barely 20 percent at present, making investment regime more friendlily for the potential investors. ${ }^{3}$ So there needs to be a serious alteration of policy regime to appropriate the benefits of FDI on overall development.

The mid-eighties and the nineties are characterized as the phase of intense trade openness, economic integration and globalization. Greater openness in the form of international trade accelerated adoption of technological innovations originating from the industrial countries leading to more investment in product development. Openness to trade provides access to imported inputs which embody new technology and increases the size of market facing producers which in turn raise the level of investment and affects a counties specialization in research intensive production. Thus, countries openness leads to improvement in domestic technology and helps the production process to become more efficient and enhances productivity improvement. Liberalization in trade aims to correct the domestic relative price in favor of exportable sectors. This is supposed to affect productivity growth positively.

The trade growth nexus is a contentious issue. Economic growth in some part of the world has been unprecedented over the recent decades. The export led growth strategy originates from the spill over effect of the increase in productivity by the adoption of new technology. With the increased competition domestic firms start utilizing resources more efficiently and improve their productivity. However, little evidences have been found in support of long run effect of trade liberalization. Dollar and Kraay (2001) proposed three points from analysis of their dataset. First, globalisers have an increase in trade to GDP ratio from 16 per cent to 33 per cent between 1970s to 1990s, which includes countries like China, Argentina, Brazil, Thailand, Malaysia etc. The second point is that globalisers experienced faster growth in the decades of 1980s and 1990s compared to non-globalisers and other rich OPEC countries. Among the spectacular cases are growth between 1980-84 and 1995-97 of Argentina (8.4 percentage points), China (3.9 percentage points), Mexico (6.5 percentage points) and the Philippines (6.2 percentage points). The third important finding is that globalization and income inequality have mixed results where countries like China has experienced worsening of income distribution but other countries like India, Malaysia and Thailand have experienced better income equality or lower inequality increases.

In respect with the discussion in above, the point is how far is this trend results from the increased trade openness of the countries? It is always difficult to isolate impact of one event from a host of others when things move simultaneously. The effect of increased trade on growth is absent in highly regulated countries. Excessive regulations restrict growth because resources are prevented from moving into the most productive sectors and to the most efficient firms within sectors. The strict regulations prevent some firms from entering, others from exiting, and labor from moving across sectors or across firms. If the structure of economic activity is rigid, then trade only has a modest impact on the allocation of resources across and within industries. Excessive regulation may encourage increased production of the wrong goods which are not efficient at producing. Trade could therefore have a stronger effect on growth in countries with less

${ }^{3}$ See Balakrishnan (2003) 
developed and inefficient institutions since it could both encourage regulatory reform and lead to more specialization. The poor regulatory structure does to generating growth through trade.

There is a debate whether openness is the most important factor for growth. Rodrik (2002) suggests that institutions matter more for growth in the very long run. On the other hand Dollar and Kraay (2002) proposed that trade is more important for mediumterm growth. Bolaky (2004) proposed that contribution of trade is limited for the highly regulated countries. The regulation is measured as the free movement of capital and labor. In the present wave of globalization barriers to trade significantly, leading to the result that world trade growth outpaced output growth. The foreign direct investment grew even faster than trade for some countries. The present wave of globalization has contributed much by the deregulation of markets in the advanced countries, with the advent and the spread of micro electronic based information technologies and its intensive use in production and communication, the globalization of financial market and rapid change in the policy orientation in the developed countries.

The common perceptions on trade liberalization as an integral part of globalization are that a nation that opens its economy to the outer world experienced a rapid economic growth. This phenomenon can be analyzed through Hecksher-Ohlin-Stolper-Samualson theorem of equalization of relative factor prices. Free movement of factors of production across national frontiers is the most important assumption which is the prime source of discontent with globalization. One possible explanation of not gainful development of the poor people from trade liberalization from trade liberalization is the lack of labor mobility. There exists a complex nexus between openness and agriculture. In several developing and least developed countries a large number of people are dependent on agriculture. Primary sector often face adverse terms of trade movement. The exports for labor intensive manufacturing export by developing countries are rapidly becoming oversupplied. This is due to low cost labor in these economies and increased outsourcing and relocation of labor intensive production from countries where wages increase faster than labor productivity. The share of primary commodities in total non oil exports have declined rapidly for all countries. People who gained from trade are mostly involved in commercial export producing sectors. So if the export industry employs more people they would be benefited significantly from the expansion of export.

Like India in majority of the developing countries primary sector is relatively labor intensive. The expansion of trade would benefit the labor class whose livelihood depends on it. The indirect effect of it could spill over to the other agricultural allied activities. In this way trade liberalization heart the poor people (Bardhan, 2001). The aim of liberalization is to access market but India's market access in the West has not improved in any significant way. The real culprit is the protectionist measure by the developed countries. As far as agricultural trade is concerned the door for importing is shut for most of the developed countries. Non tariff barrier were raised against Indian export like marine products, pharmaceutical items, process food items and so on. The proposal of agricultural trade liberalization has been fail in every negotiation in past. The professionalism of the developed countries harms lots of poor in the developing countries. A special consideration in terms of implementation should be given to those countries in which more than one half of the population dependent on their agriculture 
sector. This would help in improving the efficiency of the trade regimes in a globalized world.

The percentage changes in export and import volumes by level of development are presented in Table 1. Variations in the growth rate of developing countries is higher than those of developed and transition countries. In 2001 both export and import growth rates are negative. Two other exceptions are growth rate of export from transition countries in 1999 and import growth rate of developing countries in 1998. The growth rate in 2000 is the highest.

Table 1. Percentage change over the previous years in export and import volumes by region and economic grouping of countries.

\begin{tabular}{|l|c|c|c|c|c|c|c|}
\hline Regions \\
\hline A. Export Volume & $\begin{array}{c}1990- \\
1995\end{array}$ & 1996 & 1997 & 1998 & 1999 & 2000 & 2001 \\
\hline World & 6.0 & 6.1 & 10.7 & 5.0 & 4.8 & 10.8 & -0.9 \\
\hline Developed Economies & 5.3 & 4.9 & 10.0 & 4.6 & 4.3 & 9.2 & -1.2 \\
\hline Developing Economies & 9.0 & 6.9 & 12.5 & 5.6 & 7.1 & 13.9 & -1.5 \\
\hline Transition Economies & 5.0 & 6.5 & 10.4 & 5.1 & -1.7 & 13.0 & 8.7 \\
\hline B. Import Volume & 6.5 & 6.9 & 9.9 & 4.3 & 6.0 & 10.2 & -1.0 \\
\hline World & 5.6 & 5.3 & 9.4 & 7.7 & 7.0 & 6.4 & -1.6 \\
\hline Developed Economies & 10.1 & 6.4 & 10.5 & -3.8 & 5.6 & 19.6 & -1.1 \\
\hline Developing Economies & 2.5 & 16.0 & 13.7 & 4.7 & -8.8 & 15.0 & 12.7 \\
\hline Transition Economies &
\end{tabular}

Source: Various issues of Trade and Development Report, UNCTAD

\subsection{Globalization and the Poor in Developing Countries}

There is a growing interest in analysis the effects of globalization on the world distribution of income in general and its impacts on poor in the developing countries in particular. However, yet there is no clear consensus on whether globalization can hurt the poor and to what extent. In addition to the determination of the impact and its direction, it is important to distinguish between the short and long term and to quantify the differences in the impact of globalization on the poor. Poor countries which embrace globalization witnessed faster growth in prosperity level than countries which have stayed away from this process. Some Asian countries have able to reduce the gap between themselves and western countries. The strongest claim on the debate of income distribution and poverty has been emanated form World Bank research covering the recent phase of integration of the world economy. The report shows that between 1980 and 1998 the number of poor in the world have come down by 200 million. However, the decline in poverty trend is not surprising considering the two fastest growing countries (India and China) in poverty reduction, where most of the poor resides.

However, the most ardent pro-globalizer cannot deny the fact that globalization can hurt the poor in the short term. The proportion of world population living in absolute poverty is lower than 10 years ago. The short term impact of globalization may hurt poor in the form of rising unemployment, resulting in greater poverty of low or 
unskilled workers. The intensive competition pressure on domestic firms throws the low skilled workers out of business. Due to low degree of labour mobility, wage inflexibility across sectors unemployment is bound to rise which in turn worsen the poverty and income distribution. At the global level the poverty is declining, but the inequality trend is mixed. Countries that have participated in the globalization process have grown considerably. However, globalization can not be seen a remedy to cure poverty. It has the combination solutions connecting to international community and self-help potential of the poor country themselves. The empirical evidence suggests that the incidence of poverty is highest among the countries which have minor participation in the global market. The highest incidence of poverty found in many African, some South Asian and Latin American countries. During the last two decades India and China have achieved economic growth without commensurate reduction in income inequality because of the preponderance of urban centric growth structure. Many rural areas have not benefited from the positive development and the gap between regions has alarmingly increased.

It is to be noted that the poor in both developed and developing countries are subject to both positive and negative effects of globalization. The effects in developed countries include the fall in real wages, increased unemployment among the low skilled labor force, the training of unskilled and improved their labor productivity, while in developing countries outsourcing and increased trade may have positive impacts on employment, productivity, technology transfer and living standards. In developed countries, poor enjoy better social safety net, while in the developing countries they lack such protection to withstand in adverse circumstances.

For most of the developing countries export of their principal product comprised of low technology items. Such industries are not able to cope with the demand generated by trade liberalization and opening up to the global economy. Trade liberalization enables firms to import higher technology which in turn benefit their operation and productivity in the long term. However, higher technology requires highly skilled workforce. So the demands for low or semi skilled laborers are bound to decline (Winters, 2002). Low skilled workers are the most vulnerable in the process of globalization unless their skills are improved adequately. Thus, the low-skilled workers are much more likely to oppose freer trade and immigration than their more-skilled one.

Empirical estimates of the impact of trades on unskilled workers suggest the negative effects on unskilled labor conclude that trade has played a major role in rise in skill premium rather than skilled based technological change. Miller (2001) demonstrates that globalization explains a significant increase in earning inequality for declining relative wage of unskilled workers in the US since the late 1970s. Eckel (2003), in analyzing the role of wage inequality in labor market adjustment to international trade and biased technological progress shows that the changes in relative wages are independent of wage rigidities, but wage inequality is affected by capital market integration.

Human diversity represents a significant challenge before globalization. The movement of labour has not been occurred as it should be, although some limited movements of laborers are seen in the form of migration of high skill labor from developing to the developed countries. The unfavorable development to the developing countries is due to the political situation in these countries and their insufficient infrastructure for 
development and inability to use their human resources in an effective way. As Robertson (2004) pointed out that the key to sustain globalization lies in continued democratization and empowerment. The wave of privatization strengthens the short term profit maximizing strategies and the monopolist control at the cost of investment in human capital and infrastructural development. The consequences of which are witnessed by increased inequality, escalation of regional tension, worsened by war and debt.

Giffen (2003) proposed sets of radical and neo-liberal reforms as a globalization package. In Giffen's view radical reform involves the removal of labour mobility across countries and also abolition of property right in knowledge. Neo-liberal reforms calls for further liberalization of international trade and strengthening of the WTO in its role as creator of equitable rules of the game in the sphere of trade. The developed nation's resistance to increased liberalization of trade with agricultural commodities conditional on improvement in labor relations and production-related environmental is difficult measures to justify given the state of technology in developing countries and their infrequent competitive advantages.

The economic growth is associated with many problems (Giffin, 2003) which is reflected in the form of increase in perpetuation of global income inequality and poverty. But this problem is associated with the absence of effective democratic institution which can govern different policy issue effectively. Globalization is associated with the economic costs of programmes by the governments to redistribute income to the poor and to provide economic and social securities to their citizens. According to Giffen (2003), stressing the need for global economic development provided that it is resulted by democratic institutions of global governance. But there is a conflict between markets led greater globalization and democracy. Some of the successful redistributive policy includes - Nordic social democracy, East Asian land reform, the Costa Rican welfare state, egalitarian distribution of health services and nutrition in Sri Lanka and wage compression in Singapore. ${ }^{4}$ Two Indian states, Kerala and West Bengal were successful in land reforms which resulted in improving well being of the poor.(Besley, 1998)

\subsection{Other Effects of Globalization}

Not all countries are equally capable of resisting the shocks of globalization. The impact of globalization can be looked from different perspectives. Empirical evidence suggests that countries those opened up saw their income grow many times than who did not open up. James (2002) analyses the causes in terms of transaction costs, focusing on the information and communication technologies as well as technical change and foreign investment that derives from globalization and their application to Africa. Globalization helps countries to get access to new technology and new organizational tools. By breaking the rigid conditions it also helps countries to get access to foreign capital. The effects of globalization on skill premium, unemployment, and the social policies of countries are addressed by Ethier (2002).

Empirical literature lend support to the fact that globalization gives premium to the people with high level of skill, high education level and high entrepreneurship. The

${ }^{4}$ See (Bowles, 2001) 
skilled biased technological change in manufacturing with developing countries has definitely had adverse effect on the demand for unskilled, uneducated and marginalized workers. For developing countries, on the other hand, the fall in demand for low skilled workers is coincided with the emergence of service sector long before the onset of recent phase of globalization. Service sector accounts for the generation of bulk of employment in both industrialized and industrializing countries. Therefore, the economy wide changes in the demand for low-skilled workers can be explained by the developments in the service sectors. However, the net employment effects might be marginal.

There has been an intense link between globalization and income inequality. Lindert and Williamson (2001) and O'Rourke (2001) highlighted that the increased world inequality has been driven by between-country rather than within-country inequality. It follows therefore, that globalization will have very different implications for withincountry inequality. The direction of impact of globalization on within-country inequality depends on the participating country's policy to exploit it. If globalization factors are taken out, the source of within-country inequality in the lagging countries might responsible for poor governance and non-democracy. In their conclusions, Lindert and Williamson (2001) classify the influence of globalization on inequality into five observations. First, the widening income gaps between countries integrating into the world economy probably have been reduced. Second, within labour-abundant countries, emigration and the opening up to international trade before 1914 did lower inequality. Third, within labour-scarce countries, immigration and the opening up to international trade raised inequality. Fourth, accounting for all international and intranational effects, a greater degree of globalization has reduced inequality. Fifth, with the integration of countries and economies, inequality has become lower than under segmentation.

Despite its inequality impact, globalization can be viewed as welfare enhancing with the opening up of trade and investment flows. The increased competition within and between countries have increased efficiency extensively. The problem associated with globalization is that it is closely associated with regionalization. The regional arrangements reinforce globalization by lowering policy restrictions to trade between countries and stimulate within the region. This is awful because they work against globalization by stimulating trade inside a region. The cost of which is bound to fall on those weaker countries who are left outside the regional or economic blocks. The possible risk emerged in the form of military conflict among the regions is another side effect. The equitable distribution income posed a major challenge of globalization of the world economy.

There arises a worldwide polarization of income distribution. Rich countries reap most of the benefits of globalization leading to the inequality and potential conflicts among nations (Intriligator, 2004). Some argued that nations that gained most from globalization are those of poor ones that changed their policies to make use of it, while the ones that gained the least did not (Lindert, 2001). Although some remarkable movement of some East Asian countries comparable to that of the rich nations. At the national level a particular group of people because of better education, past training, personal contacts and access to modern financial system are able to take advantages of globalization offers. Thus, groups economically better off earlier are in a better position to take advantages of globalization process. 
The effect of financial integration with the rest of the world is a debatable issue. The financial globalization has been associated with both risk and benefits. ${ }^{5}$ The risk involved in capital flow is considerable. The capital inflows of the 1970s and early 1980s to developing countries lead to the debt crises started in Mexico in 1982. To solve the debt crisis of the 1980s, Brady Bonds were created with the subsequent development of bond markets for emerging economies. Again we saw it during the Mexican crisis of 1997-98. Portfolio flows were severely affected by the advent of the 1997-98 Asian crises and Russian crisis. When a country first opens their financial sector volatility and crisis might arise in the short run if the domestic financial sector are not prepared to regulate and supervised properly. In the long run with the development of financial sector volatility tends to decrease following liberalization and integration with world markets. Despite the risks the net benefits of financial globalization can be large if they are well managed. The diversity of source of funding reduces the risk of credit crisis. Borrowers can now raise funds by issuing stocks or bonds in domestic securities markets or by seeking other financing sources in international capital markets.

In the open financial market borrower and investor can now finance physical investment more cheaply and investors can more easily diversify internationally and modify portfolio risk to their preferences. This encourages investment and saving, which facilitate real economic activity and growth and improve economic welfare. But in the more integrated world with weak regulated banks and financial institutions leads to more vulnerable financial markets. Thus, sound macroeconomic fundamental is the key to manage the crises more efficiently. Country with very low degree of integration with the world market and underdeveloped financial markets should ensure the shock absorbing capacity. Governments are left with fewer policy instruments to manage the internationalization of financial services. Other view is that for underdeveloped financial market would benefit from full financial liberalization if the fewer intervention and policy instruments.

One of the major sources of discontent of globalization is the failure to freer movement of labor which is abundant in most of the developing countries. The forces of globalization don't allow labor to play freely. The regime of international technology transfer is much more restrictive, hindering the rapid development for the late industrializing countries. The most important reason put a ceiling on the freer movement of labor is the desire on the part of the rich countries to preserve their labor through tighter immigration policy. Increased mobility of labor would enhance knowledge and technology acquisition and welfare equality by its equalization effects on wages. The conscious and explicit state intervention prevents the emergence of global market of labor. On the other hand capital is freely mobile by the virtue of ownership of large financial multinationals by the developed countries. This contradiction needs to be solved to get the maximized benefits of globalization across the world.

Gomory and Baumol (2004) pointed out that globalization may suffer from economic damage for some group of people including developed ones. Nevertheless, the increased competition pressure resulting from globalization enhances innovation and growth leading to beneficial effect in the long run for every nation. Bhagwati (2004)

${ }^{5}$ see Kindleberger (1996) and Bordo, Eichengreen, and Irwin (1999) for detailed account of crises. 
pointed two main groups of the critics of globalization. Some have deep antipathy of globalization composed of an anti-capitalist, anti-globalization, and acute anticorporation mind-set. There are others who consider economic globalization is the cause of several social ills today, such as poverty in poor countries and deterioration of the environment worldwide. By careful revision and demonstration that globalization advances rather than hold back various social causes such as gender equality, reduction of poverty.

Stiglitz (2004) argued that developing countries which manage globalization process well have received benefits in the form of rapid economic growth. But the most common phenomenon is globalization has not been well managed which may have adversely affected growth and poverty for some countries. Increased financial arrangement increased risk and force the developing countries to absorb risk. But developed countries enjoy comparative advantage in absorbing risk at the cost of developing countries that have a comparative disadvantage. The author identifies eight channels through which the adverse effect of globalization took place. The increased risk those developing countries likely to face from the mismanaged globalization which can have adverse effect on growth. Thus, nations should design policies to mitigate the risks.

The success story of China and Korea pointed out that by tactful governing and regulating the globalization process can avoid the potential harmful effects and reap full advantage of it. China has achieved its aim of quadrupling its GDP in the two decades from 19980 to 2000 and trying to hold it for the next two decades. (Klein, 2004). Indian used to achieve annual growth rated of about $5 \%$ in some years but its growth rate is susceptible to agricultural production. Now, Indian excels in software and finance and strives for annual growth rated of 7\% during most years. Intrilligator (2004) opined that globalization can cause international conflicts; it can also contribute to their cooperation to treat economic and other treats facing the nations. Barro (2004) points out that the present Administration in United States does not seem to be excessively committed to free market.

In recent years the some Western countries have erected many new non tariff barriers or imposed de facto trade sanction against Indian exports under the pretext of labor standard, technical standard, sanity standard and others. These mercantilistic policies slowed down the process of globalization and growth and involve a great deal of wasteful spending. The most important barrier to globalization do not arise from the traditional borer-type measures such as import tariff, quantitative restrictions and limitations on the flow of foreign capital but from the diversity of national institutional arrangements. (Rodrik, 2004) Tanzi (2004) highlighted the need for increasing public spending to upgrade the countries infrastructure, improve their institutions, financial eventual costs of corrections in policies and replacing the traditional primitive and inefficient system of social protection with a minimum, modern safety net.

\subsection{Information and Telecommunication Technology and Globalization}

The sudden prominence of the world wide wave changes the way of international relations in the era of globalization. Now the global communication system links all regions on the planet instantly along with the revolution of global transportation 
system. The evolution of communication through information technology is one of the key elements of globalization. The inventions of new devices of communication like fax machine, mobile phones, computer, and internet have made the communication network much cheaper and more accessible to the common people. The efficient commutation network played a vital role in the growth, productivity and new employment opportunities. The micro processor and cheap memory revolutionized the communication industry in 1980s. The rapid decline in the real price of telecommunication provides impetus in the global networking of computing through internet. The tale density gap between middle income and low income countries has been rising rapidly.

The WTO Negotiation on the Basic Telecommunication successfully mandated on the liberalization of telecommunication market starting from $1^{\text {st }}$ January, 1998. Sixty nine countries agreed in the negotiation. Many of them agreed to lower or remove domestic barriers to intervention on competition in the area of local and long distance and satellite services. It was agreed on the market access, the adoption if a regulatory principle, liberalization of FDI rules and satellite offers. Fifty nine countries agreed to adopt transparent, pro competitive regulatory principles, representing majority of the WTO telecommunication market. Forty four countries agreed to permit significant inward foreign direct investment (FDI). Fifty countries guaranteed market access for all domestic and international satellite services and facilities. Investment in information and communication technology (ICT) infrastructure is found to positively affect the inflow of FDI to developing countries. The flow of FDI also affects positively the ICT infrastructure development. Thus, there is a two way causal relationship between flow FDI and ICT infrastructure (see Addison and Heshmati, 2004).

In many countries the communication industry has been transferred from public ownership to private through the increased waves of privatization. So, global communication network have challenged the policy makers to get used to new international relations. The global communication network and Web have changed the way of integration of countries. The faster and quicker delivery of information shifts the attention of the people, organization and government to any particular global event (Baylis, 2001). The success of developed countries in inducing rapid changes in communication area is in contrast to the failure of developing countries to eliminate trade barriers to agriculture in the WTO negotiations.

The real net capital inflow to developing countries follows a cyclical pattern. The post war cycles are not the first episodes of rapid expansion and contraction of capital flows to the developing countries. They have occurred with varying frequency under different circumstances ever since the new states have emerged from colonial rule. Not always the cycle ended with financial distress. From the longer term perspective capital flows to developing countries appear to be at the end of a 10 year cycle of expansion. The first begins in 1970s and second in early 1990s and ending with the recent slowdown. Similar terms of net inflow took place to the emerging markets from 1974 to 1981 cumulative net inflow in constant (2000) dollars amounting to \$1.155 billion compared to $\$ 1.243$ billion between 1992 and $2001 .{ }^{6}$ However, attracting foreign direct investment does not ensure the host countries’ economic benefits.

\footnotetext{
${ }^{6}$ See Trade and Development Report, 2003.
} 
In general, FDI should follow those sectors and technologies which are capable of generating sizable growth in productivity, value added and employment. However, much of the FDI are being diverted to the special route of service sectors which have little impact on exports. Free market may not always lead foreign investors to transfer enough technology or to transfer it effectively and at the depth desired by the host countries. But appropriate policy can induce investor to act according to the ways that enhance the developmental impact by building local capabilities, using local suppliers, upgrading local skills, technological capabilities and infrastructure. Attracting FDI is important is tempting foreign affiliates to transfer technology to domestic firms to create local research and development (R\&D) capacity. The increased FDI inflow have failed to boost transforming the composition of output towards high value traded good and improving export potential. The increased capital flow needed to close the trade gap have in turn added to the external deficit not only through increased bet servicing also through adverse impact of the operations of foreign owned corporation on the current account (for example Brazil and Argentina).

One of the important areas of concern is that the rapid growth of trade has not been translated into dynamic economic growth. The rate of growth of world GDP has been decelerating since the mid 1960s; it was 5.1 per cent during 1965-74, 3.7 per cent during 1970-79, 209 per cent during 1975-87, 3.2 per cent during 1980-89, 2.8 per cent during 1985-94 and 2.5 per cent during 1990-99. ${ }^{7}$ But from the perspective of individual countries, the recent globalizers have experienced an increase of their growth rates, from 2.9 per cent per year in the 1970 s to 3.5 per cent in the 1980 s, and 5.0 per cent in the 1990s. (Doller and Kraay, 2001) There are some important groups of countries growing faster than the rich countries and catching up, while the nonglobalizing part of the developing world is falling further and further behind. As for the current example, China and India constitute an important group which is growing at a faster rate than the rich countries, reducing the existing large gap in welfare gain and technology between the countries.

Outsourcing acts as a mitigating factor of the debate of international migration. Outsourcing reduces the need for cross-border migration which can help to overcome the battle between labor exporting and labor importing countries. It was based on the assumption that a competitive advantage would be gained if external suppliers were contracted to carry out non-core processes more efficiently and effectively. (McCarthy, 2004) As a result of the evolution of information technology many of the services which in the past had to be managed at in the host location can now be spread to and delivered from remote locations. These types of services include IT enable services (ITeS), business process outsourcing (BPO), which are for the most part facilitated by information technology. Some developing countries, especially India benefited because of competitive advantage to deliver quality business services at lower cost. They are being flourished by providing services related to software application, management services and the like.

Now any governments can not deny directly the opportunities of technology and economic transformation those globalization offers, which lead to revolve through the process of transformation. At the same time government should not undermine the social security of the citizens. The accommodation of global business interests is often

${ }^{7}$ See Ghose (2003) 
portrayed in terms of surrendering of national sovereignty. There needs to redefine the economic role of the state in relation to the market. State must create the preconditions for more equitable development, bargain with the outside capital to improve the distribution of gains from cross border transaction, practice if prudent macro economic management of the economy so as to reduce vulnerability and steps in actively to minimize the social cost associated with globalization. (Nayyar, 2001) A number of measures could reduce the negative impact of the rapid globalization process. Nayyar and Court (2001) identified the main ways in which the need of good governance and the strengthening of policies for the world economy. They proposed a new structure of governance, reforms and new institutions are required to protect the poor peoples in the developing countries.

\section{THE DATA SOURCES}

The database created by Kearney/Foreign Policy magazine $(2004)^{8}$ is used for the computation of the globalization index. It constitutes a small balanced panel covering 62 countries observed for the period 1995-2001. It is originally collected from national sources, international organizations and financial institutions. In this paper we examine the process of globalization through the lens of four major components. For each sample countries the data covers four groups of indicators - economic integration, personal contacts, communication technology, and political engagement. These are expected to act as a proxy for most of the channels through which globalization affect the nations' economies. ${ }^{9}$ Before computation of the index let's consider each of these factors in turn.

Economic factors underlying the globalization process consists of four variables: trade, FDI, portfolio capital flows, and income payments and receipts. All four variables are given as a share of GDP. The trade variable includes total trade and is measured as the sum of trade of goods and services. FDI is measured as net inflow of FDI. Portfolio flows are measured as the sum of portfolio inflows and outflows. Income payments and receipts include the compensation of non-resident employees and income earned and paid on assets held abroad.

The second determinant of globalization is for personal contact. The best possible ways through which personal contact occurs among the countries are: international telephone traffic, international travel and tourism, and transfer of payments and receipts. Telephone traffic is defined as the per capita sum of incoming and outgoing calls. It is obtained from the International Telecommunication Union (TU) and World Telecommunication Indicators database. The travel and tourism includes the share of travelers entering and leaving a country in relation to its total population. The variable for transfers and payments is measured as the total of in- and out-transfer payments as a share of total GDP produced.

The third component is technology transfer. Technology transfer takes many forms. Due to non availability of data this component is builds on three variables: internet

\footnotetext{
${ }^{8}$ The data sources can be viewed at web sites: www.foreignpolicy.com and www.atkearney.com.

${ }^{9}$ A number of components such as financial market, environment, cultural, technology and innovation, and labor market could be added to the set of components. No data on these components is currently available.
} 
users, internet hosts and secure internet servers. These components are communication specific and not adequately reflect technology in a broad sense. The internet user variable is measured in terms of its share of total population, while internet hosts and secured servers are measured in per capita.

Finally, the political component consists of political engagement which is based on three variables, includes the number of embassies in a country, the number of memberships in international organizations, and the number of UN Security Council missions undertaken by a country during a calendar year. The personal and political components should ideally account for the domestic political situation and the flows of information supplied by the media. For detailed summary statistics of the complete set variables see Table 2 .

Table 2: Summary statistics of globalization data, 1995-2001, 62x7=434 observations.

\begin{tabular}{|c|c|c|c|c|}
\hline Variable & Mean & Std Dev & Minimum & Maximum \\
\hline \multicolumn{5}{|l|}{ A. Economic Integration } \\
\hline 1. Trade $(\mathrm{w}=1)$ & 75.770 & 49.012 & 10.500 & 340.500 \\
\hline 2. Foreign direct investment $(\mathrm{w}=2)$ & 4.830 & 5.934 & 0.000 & 44.210 \\
\hline 3. Portfolio investment $(\mathrm{w}=2)$ & 6.021 & 16.572 & 0.000 & 193.120 \\
\hline 4. Income payment and receipts $(\mathrm{w}=1)$ & 9.100 & 9.869 & 0.670 & 78.390 \\
\hline \multicolumn{5}{|l|}{ B. Personal Contacts } \\
\hline 1. International telephone traffic $(\mathrm{w}=2)$ & 101.575 & 133.333 & 0.850 & 738.320 \\
\hline 2. International travel \& tourism $(\mathrm{w}=1)$ & 77.389 & 94.888 & 0.300 & 515.60 \\
\hline 3. Transfer payment \& receipts $(\mathrm{w}=1)$ & 3.434 & 2.774 & 0.000 & 15.490 \\
\hline \multicolumn{5}{|l|}{ C. Technology } \\
\hline 1. Internet users $(\mathrm{w}=2)$ & 8.020 & 12.038 & 0.000 & 59.950 \\
\hline 2. Internet hosts $(\mathrm{w}=1)$ & 0.015 & 0.034 & 0.000 & 0.381 \\
\hline 3. Secure internet servers $(w=1)$ & 0.016 & 0.040 & 0.000 & 0.335 \\
\hline \multicolumn{5}{|l|}{ D. Political Engagement } \\
\hline 1. Embassies in country $(w=1)$ & 70.444 & 33.947 & 13.000 & 172.000 \\
\hline 2. Membership in intel. organization (w-1) & 48.732 & 11.008 & 6.000 & 77.000 \\
\hline 3. Participation in UNSC missions $(\mathrm{w}=1)$ & 26.545 & 21.261 & 0.000 & 81.300 \\
\hline
\end{tabular}

Note : w indicates weights attached to each indicator.

\section{EMPIRICAL FRAMEWORK}

The present study attempts to quantify the level of globalization of the different countries. Kearney (2002, 2003) was the first attempted to construct a database and computed a composite globalization index. The basic component of the index is comprised of economic integration, personal contact, communication technology, and political engagement. The globalization index (hereafter denoted as KEARNEY) is based on the normalization of individual variables and the subsequent aggregation using an ad hoc weighting system. The equation used to describe globalization index takes the form

$$
K E A R N E Y_{i t}=\sum_{j=1}^{J} \sum_{m=1}^{M} \omega_{j}\left[\frac{X_{j m i t}-X_{j m t}^{\min }}{X_{j m t}^{\max }-X_{j m t}^{\min }}\right]
$$


where $\mathrm{i}$ and $\mathrm{t}$ stands for the country and time periods, $\mathrm{m}$ and $\mathrm{j}$ are within and between major component variables, $\omega_{j m}$ are the weights attached to each variable, min and max are minimum and maximum values of respective variables across countries in a given year. The index is similar to that of human development index (HDI) which is based on 3 key indicators of development namely educational attainment, life expectancy and real GDP per capita.

We consider this index as a benchmark index where the weights of the components are chosen on an ad hoc basis and are constant across countries and over time. In the basic index, each of the 13 determinants of the index is given equal weight $(w=1)$. In the alternative case, a number of variables are given double weights $(w=2)$. Using a smaller set of countries, Lockwood (2001) finds the ranking of countries based on the above index to be sensitive to the way the indicators are measured, normalized and weighted together to a composite index.

Apart from Kearney index which is non-parametric there are two alternative parametric approaches to measure the level of globalization: using the principal component (Heshmati 2003) or factor analysis Andersen and Herbertsson 2003). PC analysis is a multivariate technique for examining the several quantitative analyses. Agénor (2003) used trade and financial openness to compute a simple economic globalization index based on PC analysis. In this study we use Kearney index, weighted globalization index and principal component index with variation in all dimensions. It should be noted that an aggregation of the statistically significant principal and factor components, where in the aggregation process the share of total variance explained by each index component or factor is used as weight in the overall aggregation results in identical rankings of countries.

In principal component analysis we estimate the observed variable of globalization using least square solutions. For a given dataset of $\mathrm{P}$ numeric variables at most P-1 principal components can be computed. Each component is linearly combined with the original variables with coefficients equal to the eigenvectors of the correlation of the covariance matrix and is sorted according to the descending order of the eignvalues which are equal the variance of the components. The estimate of the principal component solution is:

$$
Y_{i t}=B X_{i t}+E_{i t}
$$

where $Y_{i t}$ is an PxN matrix of the centred observed variables for country $\mathrm{i}$ in period t, $X_{i t}$ is the JxN matrix of scores of the first $\mathrm{J}$ principal components, $B$ is a PxJ matrix of eigenvectors, $E_{i t}$ is an PxN matrix of residuals, $\mathrm{N}$ is the number of observations, $\mathrm{P}$ the number of partial variables, and $\mathrm{J}$ the number of variables or indicators of globalization. Here we minimize the sum of all the squared residuals, which are measured as distances from the point to the (first) principal axis. In the least squares case, the vertical distance to the fitted line is minimized. The globalization indices indicate the level and progress of globalization for different countries over time. A breakdown of the index into its major components provides the possibility to identify the sources of globalization, and to quantify each sources impact on the global integration of countries. 


\section{DISTRIBUTION OF THE DATA}

Trade, the driving force behind a nation's economic integration, is having an average value of $76 \%$ of a countries GDP with a large standard deviation of $49 \%$, indicating wide variation of the trade share across counties. (see Table 2) The average values of FDI and portfolio share, as a share of GDP are about 5 per cent and 9 percent respectively. While the maximum value of these variables are 44 per cent and 193 per cent respectively where the minimum share is found to be zero.

The most important items of personal components are international telephone traffic. On an average telephone traffic is concerned average per capita sum of incoming and outgoing call is 101.5 with a large standard deviation of 133.3 per cent. Wide gap is there for minimum (0.85) and maximum (738.3) values. On an average 77 per cent of the travelers entering and leaving a country in relation to its population (standard deviation 95 per cent) whereas the maximum and minimum values are 0.30 per cent and 515.6 per cent respectively. The average value of the share of in and out transfer payment is 3.43 per cent of GDP with the minimum and maximum value are 0 and 15 per cent respectively.

As far as technological components are concerned the average share of population using internet is 8.02 per cent with the standard deviation of 12.03 per cent. The maximum value is found to be 60 per cent and countries with no internet connection are also found in our sample. The per capita internet hosts and secure internet server is 0.015 and 0.016 respectively.

The average number of embassies in the country is found to be 70 with the wide gap in the minimum (13) and maximum (172) values. As far as numbers of membership in international organization are concerned on an average each country has 49 such memberships. The gap between minimum and maximum values is 6 and 77 respectively. On an average each country participate 27 UN Security Council Mission, with the large standard deviation of 21.26.

\section{THE RELATIONSHIP BETWEEN THE COMPONENTS}

Correlation coefficients among the various index components are presented in Table 3. As expected, the various components are positively and mostly significantly correlated among themselves. The economic integration component is negatively correlated over time, while technology is positively correlated with time. The remaining personal and political components as well as the two Kearney globalization indices are not correlated with time.

The economic integration consists of four variables, defined largely by trade and capital flows indicators. There was a major East Asian financial crisis in the end 1997 and a crisis in the emerging Russian and Brazilian markets in 1998. These resulted in a major decline in capital flows to the emerging-market countries as well as high volatility in the East Asian financial markets. This could well explain the negative correlation between economic integration and time trend.

The application of different weights does not change the rank of the countries much. The overall Kearney index is dominated by political and economic integration. We have not decomposed the principal component index into its underlying four 
components. Such decomposition would require, first, the application of PC analysis on each component separately, and then the aggregation of the components into a single globalization index by assigning some weights to each component, or, alternatively, the use of canonical correlation analysis looking at the correlation relationship between two or more sets of variables.

Table 3: Pearson correlation coefficients, 434 observations.

\begin{tabular}{|c|c|c|c|c|c|c|c|c|c|c|c|}
\hline & Year & Eсо & Eco(w) & Persl. & Persl(w) & Tech & Tech(w) & Political & GIndex & GIndex(w) & PC \\
\hline Year & 1.000 & & & & & & & & & & \\
\hline Economic & -0.161 & 1.000 & & & & & & & & & \\
\hline Economic(w) & -0.200 & 0.988 & 1.000 & & & & & & & & \\
\hline Personal & 0.043 & 0.626 & 0.601 & 1.000 & & & & & & & \\
\hline Personal(w) & 0.035 & 0.682 & 0.660 & 0.981 & 1.000 & & & & & & \\
\hline Technology & 0.169 & 0.307 & 0.329 & 0.387 & 0.473 & 1.000 & & & & & \\
\hline Technol(w) & 0.205 & 0.314 & 0.333 & 0.400 & 0.484 & 0.992 & 1.000 & & & & \\
\hline Political & 0.067 & 0.045 & 0.103 & 0.099 & 0.136 & 0.397 & 0.385 & 1.000 & & & \\
\hline GIndex (K) & 0.041 & 0.708 & 0.725 & 0.731 & 0.793 & 0.765 & 0.763 & 0.573 & 1.000 & & \\
\hline GIndex(KW) & 0.023 & 0.756 & 0.777 & 0.734 & 0.806 & 0.767 & 0.772 & 0.496 & 0.991 & 1.000 & \\
\hline PC & 0.297 & 0.353 & 0.392 & 0.426 & 0.490 & 0.699 & 0.704 & 0.802 & 0.832 & 0.796 & 1.000 \\
\hline
\end{tabular}

Notes: Kearney (K), Kearney Weighted (KW), and Principal Component (PC) globalization index (GIndex).

Table 4 reports the summary statistics of different index and its components. The unweighted mean economic component is 0.642 with the standard deviation of 0.560 . Except economic component all other index components are positively related with time. (see Table 4). The economic component is decreasing $(-0.161)$ over time, the weighted coefficient decreased further to -2.00. The maximum and minimum value widely varies between 0.050 and 3.588. The average values of other components are $0.590,0.390$ and 1.397 for personal contacts, technology and political engagements respectively. They are positively over time (personal contacts (0.043), technology (0.169) and political engagements (0.067)). The coefficients of personal components come down from 0.043 to 0.035 by attaching weights. However, technology component increased from 0.169 to 0.205 by attaching weights to internet users. The economic component is highly correlated (0.625) with personal engagements, moderately $(0.307)$ related with technology transfer and weakly correlated (0.045) with political components. The mean value of personal component is 0.590 with the standard deviation of 0.455 . Personal and technology transfer are positively correlated (0.387), while personal and political components are weakly correlated (0.099).

Table 4: Summary of statistics of globalization indices and their components, 434 obs.

\begin{tabular}{lcccc}
\hline Variable & Mean & Std Dev & Minimum & Maximum \\
\hline Economic Integration & 0.642 & 0.560 & 0.050 & 3.588 \\
Economic Integration (w) & 0.943 & 0.875 & 0.057 & 5.588 \\
Personal Contacts & 0.590 & 0.455 & 0.015 & 2.420 \\
Personal Contacts (w) & 0.758 & 0.647 & 0.025 & 3.335 \\
Technology & 0.390 & 0.557 & 0.000 & 2.856 \\
Technology (w) & 0.583 & 0.795 & 0.000 & 3.713 \\
Political Engagement & 1.397 & 0.551 & 0.006 & 2.695 \\
Unweighted Kearney Index & 3.019 & 1.471 & 1.150 & 7.937 \\
Weighted Kearney Index & 3.682 & 2.088 & 1.227 & 11.004 \\
Principal Component Index & 0.000 & 0.642 & -1.347 & 2.532 \\
\hline
\end{tabular}

Note: $\mathrm{w}=$ weights. 


\section{VARIATIONS IN GLOBALIZATION}

\subsection{Comparison of different approaches}

As mentioned earlier the globalization index as measure on the basis of Kearney and principal component are computed for each of 62 countries convening for seven years 1995-2001. The Kearney index is computed with equal weights and considered as benchmark model. Following Kearney's approach a number of economic, personal and technology factors are given higher weights. The logic for this argument is to go for a sensitivity analysis. The differences in levels of the two indices are due to differences in normalization of the variables. The range of principal component-based indices differs from those of Kearney-based indices. The mean unweighted globalization index is 3.019 with standard deviation of 1.471 whereas by using weighted system the mean value increased to 3.682 with higher standard of 2.088. So the dispersion around the mean is significantly higher in the weighted index. See Table 4.

In Table 4 we can observe large variations in the variables underlying the calculation of the index and its components. The distribution of the index components is not uniform. Political component comprised $47.27 \%$ of the unweighted index, followed by economic integration (21.27 per cent), personal contacts (19.54 per cent) and technology transfers (12.92 per cent). As far as weighted index is concerned, the components are distributed as political engagement (37.95 per cent), economic integration (25.62 per cent), personal contact (20.59 per cent) and technology transfers (15.84 per cent).

Globalization is positively correlated with time for each index with the highest value is found for principal component index (0.297). There is a decrease in the value of correlation coefficients from 0.041 to 0.022 using weighted globalization index (see Table 3). Our analysis is based on weighted globalization and its components which is more stress on some crucial components of globalization. Unweighted index components highlighted in the analysis. Such a provision enables us to compare the change in the position of the country after different weights are attached.

Since the expected effects from each indicator on the composite index are same in each of the indices, each of the three indices is suitable for analysis. However, they differ in a number of respects. The parametric principal component is more flexible by not assuming any weights on an ad hoc basis rather than estimating them. A disadvantage of principal component is that it does not allow decomposition of the total composite index into underlying 4 major components, unless each component is computed separately and then assuming some weighing system aggregated into a singe composite index. The two versions of the non-parametric Kearney index are flexible in decomposition, but suffer from ad hoc aggregation of the indicators. In this paper we avoid to select any of the indices, and instead try to analyze the results based on each index in parallel. In doing so, we account for their benefits and limitation.

\subsection{Globalization by country}

Country wise analysis of the globalization index reveals that indices are highly correlated with each other. ${ }^{10}$ The countries are ranked in a descending order according

${ }^{10}$ Spearman rank correlation coefficient: K-KW: 0.975, K-PC: 0.828, KW-PC: 0.795 
to the weighted Kearney index (see Appendix A and Figure 1). As mentioned earlier following Kearney's approach a number of economic, personal and technology factor are given higher weights. The positions of the countries with in unweighted weighted index are almost the same. Ranking of the countries differs to some extent by principal component index (see Appendix A and Figure 2).

The top ten position of globalization is dominated by European countries, with Ireland (8.829) leading group. Singapore is the second highest globalized country in the world with an index value of 8.321, followed by Switzerland (8.238), Sweden (8.125), Canada (7.175), UK (7.064), Netherlands (7.032), Finland (6.919), Denmark (6.860) and USA (6.844). The three non European countries qualified in the group are Singapore, Canada and USA. Good overall performance of the components goes together in forming highest positions. In terms of factor influencing their globalization no similar trend is found among them. For Ireland and Singapore economic and political component dominated the globalization process. While in Switzerland personal component influenced more than other factors. In Sweden both economic and political components have more influence.

Iran, Colombia, Peru, Uganda and Saudi Arabia are among the least globalized countries in the world. The low ranking is mainly due to low technological and economic components. Very likely lack of policy coordination due to their political setup, limited resources and internal conflicts may have caused cause such imbalances in the first four countries. Republic of Korea, Russia, Slovenia, Croatia and Chile are among the average five globalized countries. The economic component has identical influence among these countries but differ as far as other three components are concerned.

Figure 3: Globalization and its components for China and India

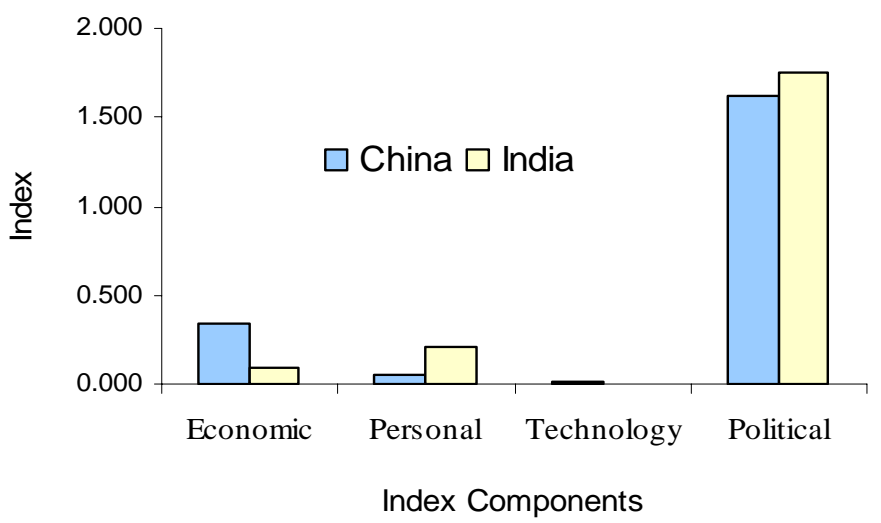

Except Singapore no other Asian countries showed a satisfactory level of globalization. From individual country's perspective it is worthwhile to compare China and India, looking at their different political setup and almost identical in population size. China has singly party rule while India is a multiparty democracy. Ranked 42nd in the world, China is marginally (0.128) ahead of India in terms of the computed globalization index. China is well ahead in economic integration compared to India, which enjoys better advantage in personal and political engagements. Figure 3 shows the breakdown of the indices into the four components for two countries. 
Table 5: Globalization index and its components in China

\begin{tabular}{cccccccc}
\hline Year & Economic & Personal & Technology & Political & K & KW & PC \\
\hline 1995 & 0.494 & 0.031 & 0.000 & 1.566 & 2.092 & 2.473 & -0.167 \\
1996 & 0.432 & 0.038 & 0.001 & 1.545 & 2.015 & 2.316 & -0.178 \\
1997 & 0.404 & 0.058 & 0.001 & 1.490 & 1.953 & 2.233 & -0.208 \\
1998 & 0.315 & 0.044 & 0.005 & 1.545 & 1.909 & 2.123 & -0.193 \\
1999 & 0.239 & 0.055 & 0.015 & 1.468 & 1.778 & 1.926 & -0.206 \\
2000 & 0.226 & 0.059 & 0.035 & 1.641 & 1.961 & 2.101 & 0.001 \\
2001 & 0.248 & 0.044 & 0.043 & 2.063 & 2.398 & 2.544 & 0.288 \\
\hline Mean & 0.337 & 0.047 & 0.014 & 1.617 & 2.015 & 2.245 & -0.095 \\
\hline
\end{tabular}

By far the largest category is political engagement, which makes up $84.77 \%$ and $80.24 \%$ for India and China respectively. In terms of components influencing globalization political factor have contributed much for both countries. In China political factor of globalization is followed by economic, personal and technological components (see Table 5). In India, political factor is the second highest component of globalization (see Table 6).

Table 6: Globalization Index and its components in India

\begin{tabular}{cccccccc}
\hline Year & Economic & Personal & Technology & Political & K & KW & PC \\
\hline 1995 & 0.127 & 0.176 & 0.002 & 1.571 & 1.876 & 1.965 & -0.192 \\
1996 & 0.153 & 0.281 & 0.003 & 1.549 & 1.986 & 2.094 & -0.207 \\
1997 & 0.128 & 0.269 & 0.002 & 1.725 & 2.124 & 2.202 & -0.129 \\
1998 & 0.070 & 0.169 & 0.004 & 1.731 & 1.974 & 2.005 & -0.137 \\
1999 & 0.053 & 0.215 & 0.005 & 1.829 & 2.103 & 2.127 & -0.040 \\
2000 & 0.050 & 0.201 & 0.008 & 1.813 & 2.073 & 2.098 & 0.041 \\
2001 & 0.090 & 0.186 & 0.010 & 2.016 & 2.301 & 2.329 & 0.229 \\
\hline Mean & 0.096 & 0.214 & 0.005 & 1.748 & 2.062 & 2.117 & -0.062 \\
\hline
\end{tabular}

India and China adopted different types of strategy on FDI for their industrial development. India followed import substitution policy which relied on domestic resource mobilization and domestic firms were encouraged in production. ${ }^{11}$ To quote from World Investment Report 2003, FDI has contributed to the rapid growth of China's merchandise export. At an annual rate China's export grew by $15 \%$ between 1989 and 2001.

In 2000-2001, about two third of the FDI to China went to the manufacturing sectors. Differences are there in FDI performance of the two countries relating to timing, progress and the contents of FDI liberalization. China opened its economy in 1979 and since then has been progressively liberalizing its investment regime. Since its opening, China has liberalized FDI in export oriented sectors. India didn't take comparative steps towards liberalization, the combination of legal and institutional infrastructure and restrictive FDI policies followed until 1991. (Nagaraj, 2003) On the other hand FDI has been much less important in driving India's export growth except in high technology activities. The low effect is due to low inflow of FDI to India. Even after a significant liberalization of FDI policies, internationalization is not necessary a dominant factor.

${ }^{11}$ See (Sarma, 2002) 


\subsection{Globalization by region}

Regionally we divide the sample countries into nine broad groups. Their mean globalization is presented in Table 7 . The mean index components by region are presented in Table 8.

Table 7: Globalization index by region: Rank in descending order of the weighted globalization index

\begin{tabular}{lcccccc}
\hline \multicolumn{1}{c}{ Political } & K & Rank (K) & KW & $\begin{array}{c}\text { Rank } \\
(\mathrm{KW})\end{array}$ & PC & Rank (PC) \\
\hline West Europe & 4.748 & 1 & 6.129 & 1 & 0.699 & 2 \\
North America & 4.672 & 2 & 5.876 & 2 & 0.748 & 1 \\
South East Asia & 2.974 & 3 & 3.731 & 3 & -0.275 & 5 \\
East Europe & 2.529 & 4 & 2.941 & 4 & -0.253 & 4 \\
East Asia & 2.061 & 7 & 2.600 & 5 & -0.339 & 8 \\
Middle E\&N Africa & 2.180 & 5 & 2.434 & 6 & -0.320 & 6 \\
Latin America & 2.011 & 8 & 2.393 & 7 & -0.235 & 3 \\
Sub-Saharan Africa & 2.131 & 6 & 2.309 & 8 & -0.496 & 9 \\
South Asia & 1.893 & 9 & 1.943 & 9 & -0.339 & 8 \\
\hline
\end{tabular}

The ranking of regions differs over the methods applied in the measurement of globalization, i.e. whether an identical or different weighting system of the nonparametric Kearney type index is applied or whether the parametric principal component is employed.

Table 8: Globalization index by region: Ranked by descending order of unweighted index

\begin{tabular}{lcccccccccc}
\hline Region & Eco & Eco(w) & Persl. & Persl(w) & Tech & Tech(w) & Political & GIndex & GInde(w) & PC \\
\hline West Europe & 1.060 & 1.661 & 1.039 & 1.417 & 0.793 & 1.196 & 1.856 & 4.748 & 6.129 & 0.699 \\
North America & 0.575 & 0.906 & 0.584 & 0.926 & 1.619 & 2.150 & 1.894 & 4.672 & 5.876 & 0.748 \\
South East Asia & 1.078 & 1.467 & 0.542 & 0.754 & 0.250 & 0.405 & 1.105 & 2.974 & 3.731 & -0.275 \\
East Europe & 0.510 & 0.701 & 0.600 & 0.709 & 0.178 & 0.289 & 1.241 & 2.529 & 2.941 & -0.253 \\
East Asia & 0.389 & 0.576 & 0.216 & 0.274 & 0.390 & 0.684 & 1.066 & 2.061 & 2.600 & -0.339 \\
Middle E\&N Africa & 0.342 & 0.447 & 0.523 & 0.619 & 0.103 & 0.155 & 1.212 & 2.180 & 2.434 & -0.320 \\
Latin America & 0.572 & 0.856 & 0.171 & 0.215 & 0.072 & 0.126 & 1.196 & 2.011 & 2.393 & -0.235 \\
Sub-Saharan Africa & 0.428 & 0.564 & 0.584 & 0.606 & 0.030 & 0.050 & 1.089 & 2.131 & 2.309 & -0.496 \\
South Asia & 0.168 & 0.208 & 0.342 & 0.348 & 0.003 & 0.007 & 1.379 & 1.893 & 1.943 & -0.339 \\
\hline
\end{tabular}

The mean index value showed wide variations across regions ranging from a high level of 4.748 in West Europe to the low level of 1.893 for South Asia. West Europe has the highest score in both Kearney and weighted Kearney method whereas North America ranked highest in terms of Principal component index. Top four positions (West Europe, North America, South East Asia and East Europe) of the regions are the same in both Kearney and weighted globalization index.

As a result of attaching higher weight to the technology factor the position of East Asia has moved up from seventh to fifth position in ranking of the weighted Kearney index. Conversely, the ranking of Sub-Saharan Africa came moved down from sixth to eights position after attaching weights to some individual indicator variables. The ranking of South Asia stands in the bottom in both unweighted and Weighted Kearney indices while in the case of the principal component index Sub-Saharan Africa has got the lowest rank. 
Figure 4: Globalization by region, North America and Pacific

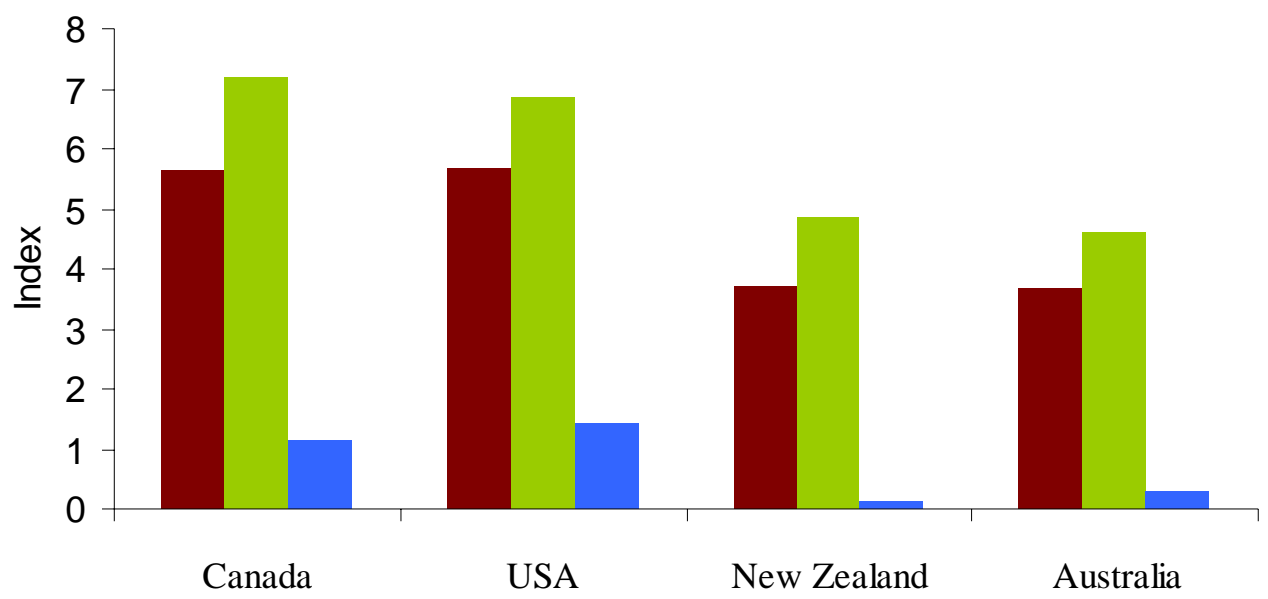

— Kearney Weighted Kearney $\square$ Principal Component

West Europe, North America and South East Asia constitute the three highest globalized regions (see Figure 4-6). Also these three regions differ in terms of individual index components. Political component is the dominant factor for all of these three regions, followed by economic, personal and technological factor for majority of the regions. In general these three regions enjoy advantages positions in any of the index components. In particular the large countries with embassies in all countries and strong positions in the US system organizations and the UN Security Council are attached quite high political index components.

Figure 5: Globalization by region, West Europe.

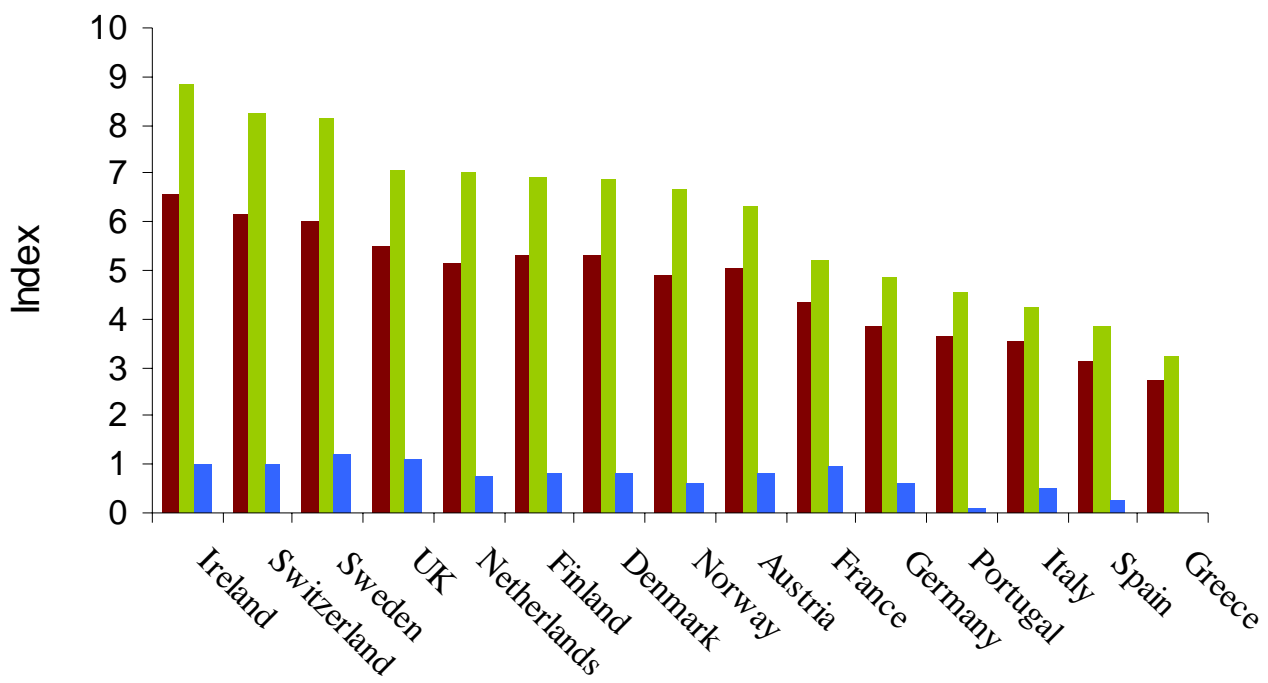

Kearney Weighted Kearney $\square$ Principal Component 
Table 8 shows the contribution of the factors in both in terms of Kearney and weighted Kearney methods. For instance, South East Asia has got the highest advantage in economic globalization, West Europe has the highest expediency in personal contacts and North America enjoys most commendable position in technology transfers. East Europe, Middle East and North Africa and East Asia are identified as the medium level of globalized region. East Europe has the advantage in all index components in the group.

Figure 6: Globalization by region, East Europe.

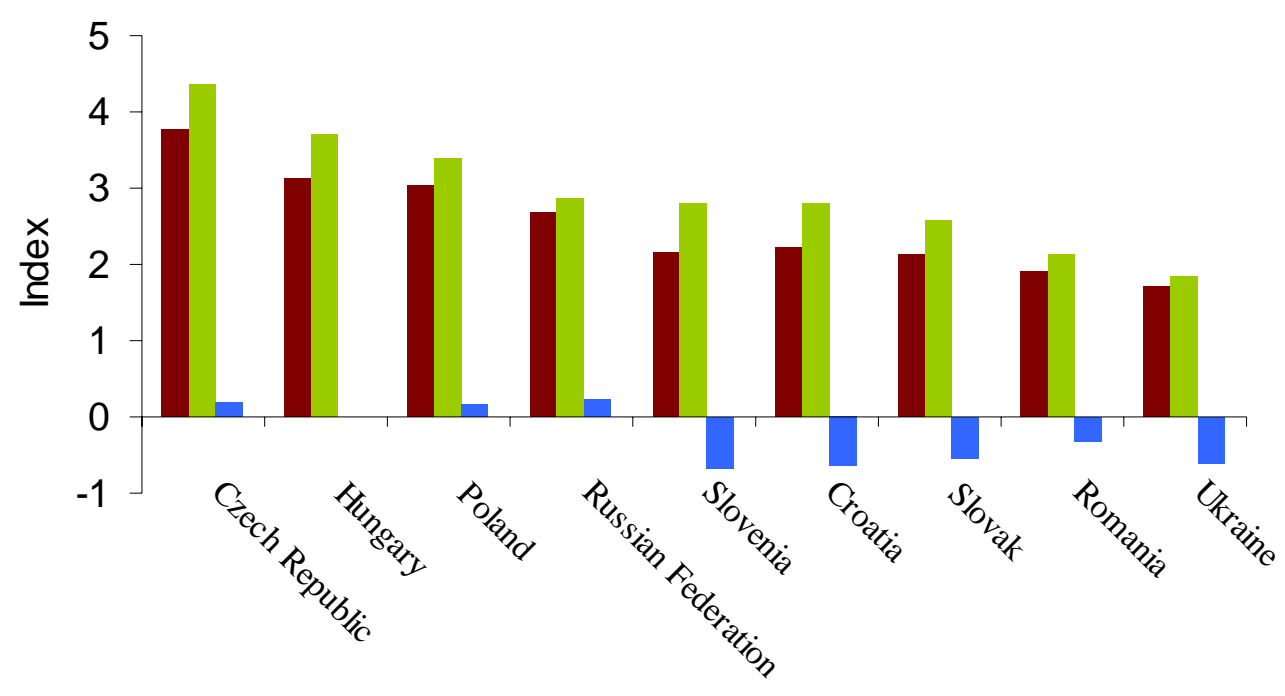

Kearney $\square$ Weighted Kearney $\square$ Principal Component

The index component differs among other two where Sub Saharan Africa has the advantage in economic and personal engagements than Middle East Africa which has better position in technology and political components. Lastly, East Asia, Latin America and South Asia are amongst the bottom three in terms of the lowest degree of progress in globalization. East Asia enjoys better advantage in technology transfer whereas for South Asia's globalization has been impacted by low economic and nearly absent technology factor. Sub Saharan Africa enjoys better progress in economic and personal factors and Latin America shows progress in technology and political engagements.

As far as other factors of globalization are concerned political component is more dominant for the least globalized regions. The reverse trend is found for technological components, where South Asian and Sub-Saharan African region ranks low in technological transfer. North America has better advantage in technology transfer followed by East Asia (Figure 7) and West Europe courtiers. In terms of political engagement they are also different. The South East Asian and Latin American region shows high economic integration, but its level of globalization is limited by relatively low personal contacts and technology transfer. 
Figure 7: Globalization by region, East Asia.

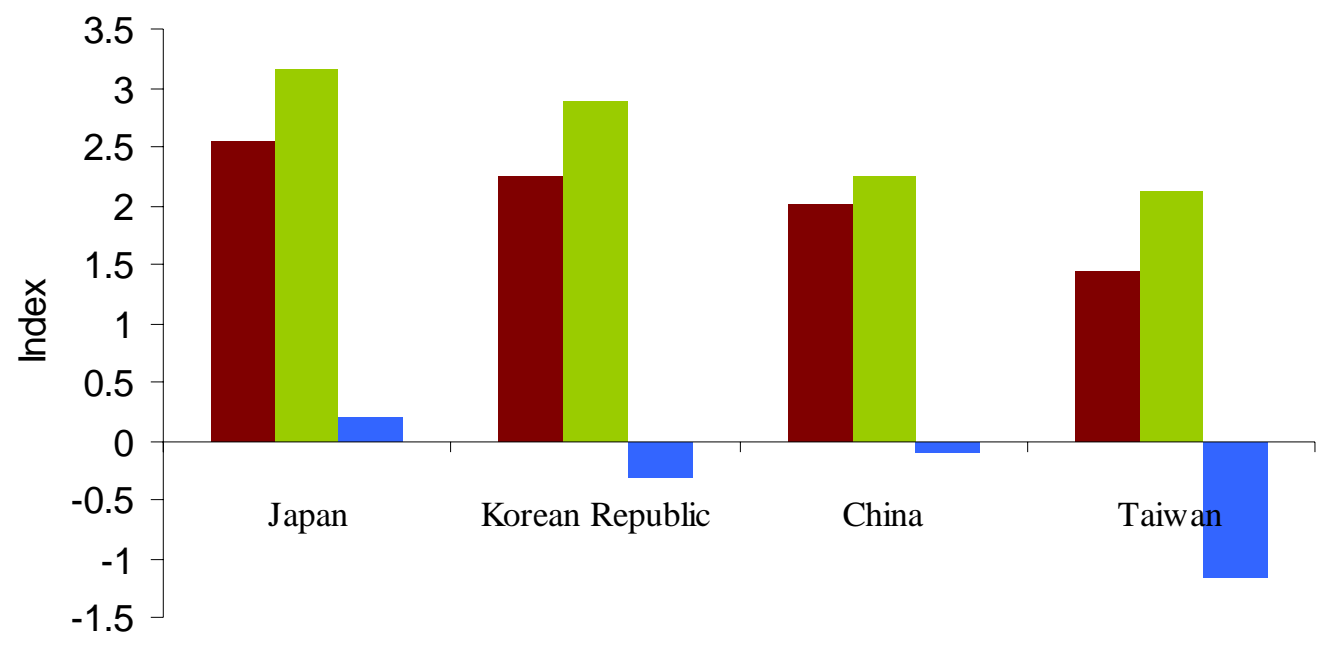

Kearney $\square$ Weighted Kearney $\square$ Principal Component

If we take out Spain and Greece all other West European countries belongs to top 20 most globalized countries. Good overall functioning of index component especially in economic and political components made them the leader. West Europe was the place of origin of Industrial Revolution continues its position as industrial leader even today. Ireland, Netherlands, Sweden, UK, Denmark and Finland witnessed a modest presence in economic integration. Economic integration and personal contacts, the driving force of Ireland's globalization, is having heterogeneous effect for other countries in the group. Switzerland racked up second position in the world and in the group, achieves good overall performance in all of its components. Being founded on technology transfer Finland outranked in the group (1.75) and second in the world.

East Europe not fared so well in global integration placed as medium globalized region. Czech Republic leading the group ranked $18^{\text {th }}$ position in the world followed by Hungary, Poland, Russia, Croatia, Slovenia, Slovakia, Romania and Ukraine. The total collapse of Soviet Union in 1990s headed the region into a period of chaotic economic, political and social transition.

North America, resides world's most powerful economy, contributed by its size, geographic, diversity and abundant natural resources. Countries belongs to this region plays a pivotal role in global economic scenario. Canada leading the group, followed by USA with its supreme power in the world of technology transmits (2.323), and New Zealand and Australia not as strong as the former. 
Figure 8: Globalization by region, Latin Africa.

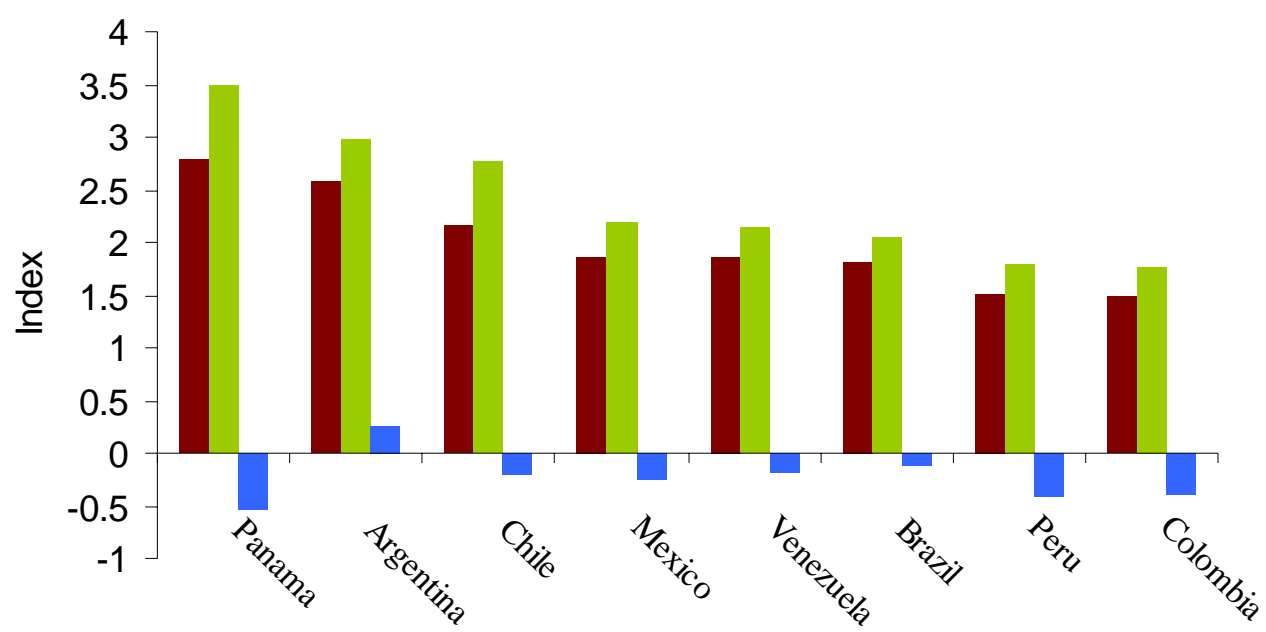

$\square$ Kearney $\square$ Weighted Kearney $\square$ Principal Component

In Latin America, Panama and Argentina have maintained considerable lead over the other countries. (see Figure 8) Brazil, the tenth largest economy in the world ranked $6^{\text {th }}$ in the region and $54^{\text {th }}$ in the world, is the largest debtor in the world. In 1960s, Brazil, Mexico and Argentina showed remarkable advancement in industrial position. Oil wealth also helped to nurture the economy of Venezuela and Mexico. But these countries were badly shaken by the debt crisis in 1980s and have failed to recuperate it from there.

Figure 9: Globalization by region, Middle East \& North Africa.

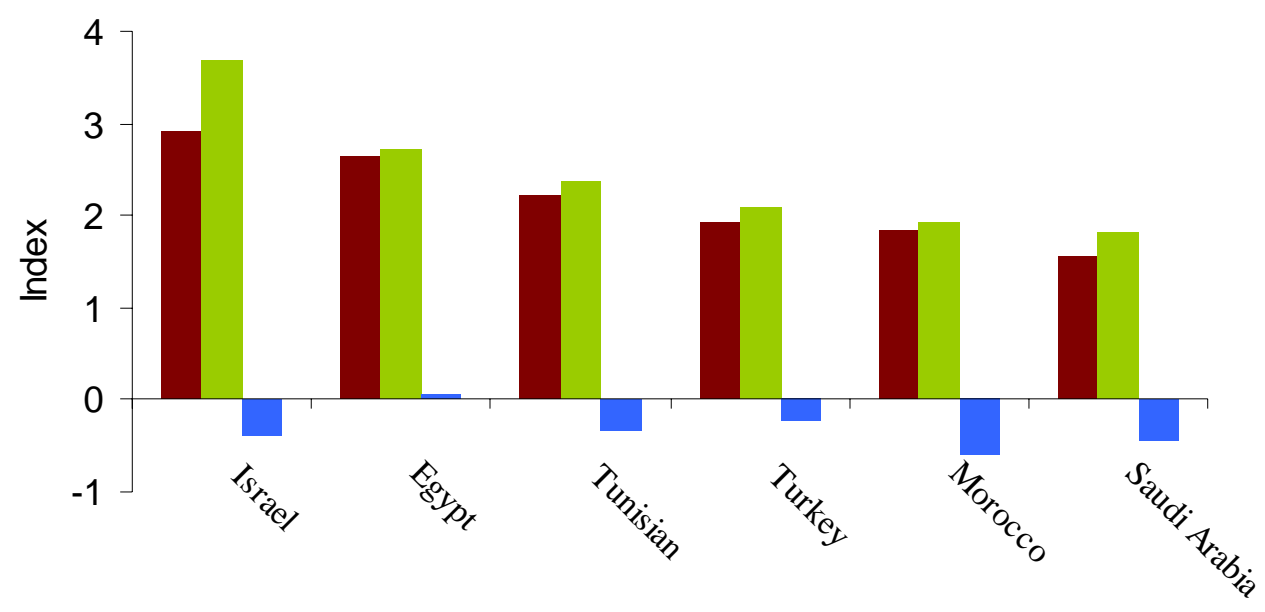

— Kearney $\square$ Weighted Kearney $\square$ Principal Component

Middle East and North Africa played a crucial role in the process globalization (see Figure 9). Israel is ahead in the group with good overall performance of the components of globalization followed by Egypt, Tunisia, Turkey, Morocco and Saudi 
Arabia. Political conflict across the region played a crucial role in disrupting the process of economic development. Civil war, conflicts across the states have jeopardized the greater international integration.

Sub Saharan Africa is the poorest and the least developed regions of the world have limited connectedness with rest of the world (see Figure 10). Nigeria is in the lead with good achievement in political and economic components. Botswana, second position in the group, has a stable, democratic setup, enjoys strong and growing economic base is leading in economic integration and personal contacts. South Africa is known as economic powerhouse and has well balanced industrial economy within the region. But failed to do well in economic integration but placed first in technology transfers within the group. The population growth emerges as a severe problem which has been outstripping economic expansion. Moreover, ethnic conflicts and the spread of AIDS exasperate the regions problem.

Figure 10: Globalization by region, Sub Saharan Africa.

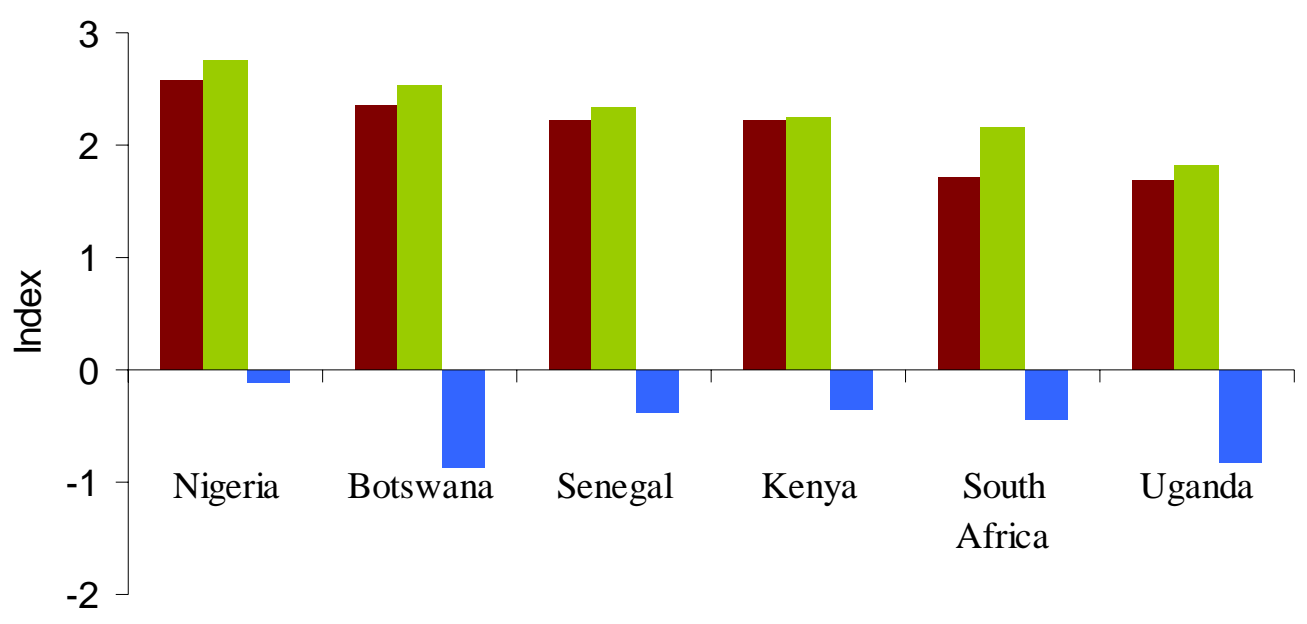

— Kearney $\square$ Weighted Kearney $\square$ Principal Component

Most heterogeneous development in globalization is found among Asian regions and countries. One the one side there are South East Asian countries, most dominant in the recent globalization process. Singapore and Malaysia are the leading the two leading country in the group. Singapore placed second in the world is now the communication can financial hub thriving with high tech manufacturing centre. Singapore experienced mild economic recession in 1990s. The government of Singapore encouraged investment by multinationals and invested heavily in the social and physical infrastructures. Malaysia, well behind from Singapore, contributed by better performance of political and economic components. Economic development in Malaysia is centered around primary sector and on the extraction of natural resources. Philippines placed bottom of the group was one of hardly hit by the Asian Economic crisis of the late 1990s. Once highly developed Philippines experienced biggest economic disappointed in South Asia. 
Figure 11: Globalization by region, South Asia.

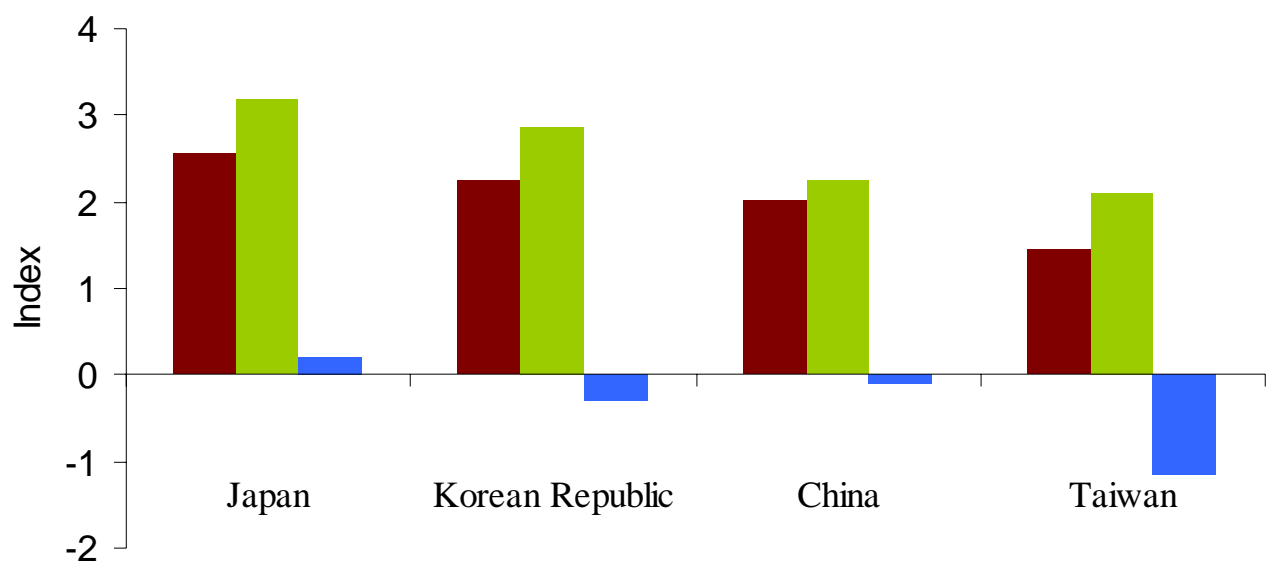

Kearney $\square$ Weighted Kearney $\square$ Principal Component

Other side made up of South Asian countries where only political components play a crucial role in their globalization campaign (see Figure 11). Countries belongs to this region appears their globalization worsen very much by near absence in technology transfer. Pakistan is leading the group with better economic and political components, followed by Bangladesh, India, Sri Lanka and Iran. The continuing geopolitical tension between Indian and Pakistan is deteriorating the globalization process in this region. Ethnic violence in Sri Lanka also appended the problem.

\subsection{Development of globalization over time}

Despite short period of observation from 1995-2001 the estimates of various approaches of globalization are capable to provide satisfactory explanation of development of globalization over time. The idealistic situation should be to weight by countries share of GDP or population to provide a satisfactory survey of the coverage of temporal changes in the globalization process. The components of globalization are able to provide break up indices over time. Both weighted and unweighted globalization are fluctuating between and the throughout the time period of the study. Between 1995 and 1997 the unweighted index rose steadily from 2.89 to 3.07, but declined in 1998 to 2.92, again increased thereafter for the last rest of the period (3.00 to 3.18). Weighted globalization index shows the same pattern of movement during those periods while the PC index increased continuously from 1995-2001 (see Table 9).

In terms of the contribution of separate components on globalization index, political factor is the most important contributor over the entire time periods. The shares of political and personal factors are fluctuating over time whereas economic factor is declining over the study period. Both weighted and unweighted economic integration increased in 1997 and thereafter remained low for the rest of the periods 1998-2001. The decline is a consequence of emerging markets with high level of protection and also the East Asian financial crisis accentuated the drop of the value. Also the 
protectionist measure by the developed countries for the primary items also contributed this fact. Only technological factor is seen in a rising tendency increased from 0.22 to 0.52 .

Table 9: Development of globalization index and its components over time

\begin{tabular}{ccccccccccc}
\hline Year & Eco & Eco(w) & Persl. & Persl(w) & Tech & Tech(w) & Political & GIndex & GInde(w) & PC \\
\hline 1995 & 0.744 & 1.162 & 0.546 & 0.710 & 0.223 & 0.320 & 1.380 & 2.892 & 3.572 & -0.204 \\
1996 & 0.725 & 1.101 & 0.605 & 0.771 & 0.316 & 0.451 & 1.372 & 3.018 & 3.694 & -0.178 \\
1997 & 0.810 & 1.226 & 0.560 & 0.714 & 0.349 & 0.493 & 1.355 & 3.074 & 3.787 & -0.143 \\
1998 & 0.577 & 0.825 & 0.566 & 0.737 & 0.402 & 0.586 & 1.381 & 2.926 & 3.529 & -0.081 \\
1999 & 0.557 & 0.796 & 0.637 & 0.821 & 0.438 & 0.659 & 1.371 & 3.003 & 3.647 & 0.024 \\
2000 & 0.562 & 0.807 & 0.617 & 0.785 & 0.479 & 0.752 & 1.381 & 3.039 & 3.724 & 0.207 \\
2001 & 0.516 & 0.685 & 0.602 & 0.771 & 0.524 & 0.824 & 1.541 & 3.184 & 3.821 & 0.373 \\
\hline
\end{tabular}

As a most globalized country, Ireland witnessed rapid progress in globalization throughout the entire study period. In the initial year the value of the index was 6.040, continued up to 6.458 in 1997. Thereafter made a jump to 10.825 in 1998 and hold the momentum till the end. For Switzerland globalization followed a stable path through out the entire period where the index ranges between 7.442 and 8.699. For the remaining countries in the group their index value varies between 6.707 and 9.118 for Sweden, 6.718 and 7.419 for UK, 6.412 and 7.564 for Netherlands, 6.222 and 7.181 for Finland, 6.191 and 8.057 for Denmark, 5.697 and 7.808 for Norway, 5.757 and 6.500 for Austria, 4.572 and 5.772 for France, 4.057 and 5.627 for Germany, 3.670 and 5.635 for Portugal, 3.678 and 4.791 for Italy, 3.120 and 4.451 for Spain and 2.880 and 3.561 for Greece.

Almost all North American countries hold its globalization at a steady level. Excluding Canada all other countries in North America strengthen their position in globalization from the 1995 level. Globalization index Canada drop marginally from 7.289 in 1995 to 7.130 in 2001. For USA, the secondly ranked country in the group picked up the index value from 6.047 in 1995 to 7.192 in 2001. The index value varies between 4.658 and 5.269 for New Zealand and 4.202 and 5.173 for Australia.

The globalization process in South East Asian countries was coincided with the economic crisis. Singapore is among the 'Asian Tiger' showed a fluctuating tendency in their globalization process. Starting from 9.184 in 1995 reached 10.125 in 1996, dropped suddenly to 7.059 in the next year, reached as low as 6.827 in 2000 . This downturn happened in the backdrop of financial crisis and the subsequent economic recession plagued in 1998. Except Malaysia and Thailand all other countries witnessed a sharp drop and the wild fluctuations throughout the entire period in their level of globalization. Singapore saw a significant acceleration in globalization 9.184 to 10.193 over 1995-96, but dropped to 10.125 in 1997 and took a nosedive to 7.372 in 2001 before touching the bottom level of 6.847 in 2000. Malaysia and Thailand hold a steady level through the time period.

Czech Republic is leading the group with good overall performance in the index components, although the index value drops from 4.873 in 1995 to 4.658 in 2001. The story is being repeated for Hungary too where the index value started from 5.018 in 1995 drop sharply to 3.858 in 2001. For other countries the index varies between 3.293 and 3.485 for Poland, 2.672 and 3.092 for Russian Federation, 2.201 and 3.658 for 
Slovenia, 2.103 and 3.028 for Slovak, 1.703 and 2.439 for Romania and lastly 1.520 and 2.361 for Ukraine.

Most North American countries found a steady advance in the globalization process. Hungary, the placed second in the group, recorded an abrupt fall in the index from as high as 5.018 in1995 to 3.858 after reaching its minimum level of 3.287 in 1999. The top ranked in the region Czech Republic hold a steady position in globalization but its index drop from 4.873 to 4.658 between 1995 and 2001. Croatia showed a marked improvement in their level of globalization increased from 1.957 in 1995 to 3.071 in 2001 although reached its peak at 3.096 in 1999.

Most Latin American countries began to open their in the late 1980s as part of their structural adjustment program. Panama topped the in the group with its strong presence in economic factor witnessed a sharp decline in level of globalization from 3.807 to 2.390 between 1995 and 2001. Chile pioneer in the reform process got better advancement from 2.387 to its top at 3.187 in 2001. Chile unilaterally eliminated quantitative restrictions and reduced import tariff to a uniform level of 10 percent by the early 1990s which resulted in the improvement in index from 2.387 to 3.187 during the study period.

Nigeria, as a leading country in the Sub Saharan group started out well at 3.135 in 1995, but its index value consolidated within the range of 2.438 and 2.937 for the rest

of the period. Botswana experienced a steady fall in the index value from 2.940 in 1995 to reach the bottom level at 2.118 in 2001. Interestingly, other low ranked countries in the region recorded an improvement in their globalization process. Their index value varies between 2.105 and 2.659 for Senegal, 2.064 and 2.479 for Kenya, between 1.640 and 2.980 in South Africa and between 1.639 and 1.938 for Uganda. Economic and political factor affected the process of globalization. Poor climatic factors continued to have a major impact on economic performance.

In South Asia, where most countries experienced a steady progress in the globalization process, only Bangladesh experienced a marginal fall in the index value. In India, the increase in the index value was more pronounced, increased from 1.964 to 2.329 over between 1995 and 2001. For Pakistan, high and the low index value varies between 2.169 and 2.507, for Bangladesh varies between 1.962 and 2.205, for Sri Lanka varies between 1.649 and 2.073 and for Iran varies between 1.226 and 1.361. Declining economic integrations and very insignificant presence of technology transfers are among the prime factor responsible holding back their globalization process.

\subsection{Changes in globalization}

The average changes in index components and composite indices are reported in Table 10. The changes are based on the mean value from previous period, neglecting the between-country variation. The level of globalization increases over time except in 1997-98 where the change is negative. As far as the components of globalization are concerned only technological component showed positive improvement over time. In 1997-98 economic component recorded a major decline. 
Table 10: Percentage change in globalization index and its components over time

\begin{tabular}{lrrrrrrr}
\hline Year & Economic & \multicolumn{1}{c}{ Personal } & Technology & \multicolumn{1}{c}{ Political } & \multicolumn{1}{l}{ K } & KW & \multicolumn{1}{c}{ PC } \\
\hline $1995-96$ & -2.59 & 10.77 & 41.96 & -0.54 & 4.34 & 3.43 & -12.62 \\
$1996-97$ & 11.84 & -7.34 & 10.32 & -1.26 & 1.88 & 2.50 & -19.79 \\
$1997-98$ & -28.82 & 1.00 & 15.40 & 1.94 & -4.80 & -6.81 & -43.52 \\
$1998-99$ & -3.42 & 12.57 & 8.77 & -0.73 & 2.61 & 3.36 & -130.27 \\
$1999-00$ & 0.86 & -3.08 & 9.53 & 0.68 & 1.21 & 2.11 & 749.59 \\
$2000-01$ & -8.10 & -2.43 & 9.37 & 11.65 & 4.78 & 2.59 & 79.93 \\
\hline
\end{tabular}

\section{INDIA AND GLOBALIZATION}

In this section we make an attempt to understand the implications of the globalization process on labor in organized manufacturing sectors. The organized manufacturing sector covers only a narrow segment of India's massive workforce, providing about $10 \%$ employment as a whole. The justification for considering the organized manufacturing labour only stems from the following reasons. Firstly, the organized manufacturing sector in Indian is highly encircled by various rules and regulations which guaranteed organised labor's rights to job security compared to other sectors of the economy. Secondly, despite its small presence in export the organized manufacturing sector constitutes a subset of total manufacturing segment in India it remains at the heart of the manufacturing activity in India. Therefore, one can view the implications of globalizations on labour marker in India through the lens of the organized manufacturing sectors. Lastly, ready availability of quantitative data and other information on organized manufacturing activity compared to the other sectors.

Table 11: Total inflow of foreign capital in India

(US \$ million)

\begin{tabular}{lcc}
\hline Year & Amount of FDI Inflows & $\begin{array}{c}\text { Foreign Portfolio } \\
\text { Investment } \#\end{array}$ \\
\hline $1991-1992$ & 129.4 & 4 \\
$1992-1993$ & 392.5 & 244 \\
$1993-1994$ & 678.5 & 3567 \\
$1994-1995$ & 1483.4 & 3824 \\
$1995-1996$ & 2367.5 & 2748 \\
$1996-1997$ & 3367.7 & 3312 \\
$1997-1998$ & 4405 & 1828 \\
$1998-1999$ & 3544.9 & -61 \\
$1999-2000$ & 3604.7 & 3026 \\
$2000-2001$ & 4744.6 & 2760 \\
\hline
\end{tabular}

Source: Report on Currency and Finance (2002-03), Report on Currency and Finance (2002-03), Reserve Bank of India,

Note: \# represents the amount raised through Global Depository Receipts (GDRs) and American Depository Receipts (ADRs), Foreign Institutional Investment (FIIs) and Offshore funds.

Beginning form 1980s, the Government of India undertook a series of adjustment in industrial policy for opening the door of the economy for FDI and providing long term cover to foreign investment. But 1991 was marked as the watershed year for opening up of the economy on a much bigger scale. India's step towards massive liberalization was motivated by the external payment crisis and other political factors also provided 
the impetus. It had to approach IMF for fresh loans to clear its fallen debt due. Thus, on the behest of IMF and World Bank India sincerely followed structural adjust programme which contain loaded prescriptions like trade liberalization, lifting up restriction on foreign direct and portfolio investments, current account convertibility in phases and partial capital account liberalization, shifting towards market-determined exchange rate regime, beginning the privatization process and measures to pass on substantial portion of the domestic market to the trans national corporations (TNCs). For inflow of FDI and foreign portfolio investment to India post 1991 see Table 11.

Since independence, India had adopted the Soviet style planned economy, relatively closed or protected, with trade and foreign investment playing a limited role, a significant agrarian sector marked by low per capital income and income inequality. Still agricultural growth is the major force in stimulating domestic demand for industrial goods. Organized manufacturing sector in India includes all public sector enterprises and all non agricultural establishments employing ten or more workers. The post-globalization phase of Indian manufacturing industries is facing three-pronged attacks. A segment of manufacturing is now getting linked with the global capital and technology. This has been significant challenge for the domestic industry, its selfreliant industrial development and the industrial growth.

Firstly, the domestic industry irrespective of size and class is encountering the problem of demand deficiency. It is to be noted here that unlike the industries in East and SouthEast Asia dependence of Indian industry on international trade is insignificant. India accounts for less that 1 per cent share in world trade. Hence, the major demand for the industry stems from the domestic market. The decade of nineties characterize large volatile fluctuation in the market demand. Pent up demand for the consumer durables was absorbed with one time hike in wages and salaries in the public and organized sector in the mid-nineties. By that time the entry of the foreign firms and products in the Indian market as a result of increased openness eroded significantly the market share of the domestic industries.

Secondly, the domestic industry has been facing stiff competition in the domestic market from the foreign firms and products in terms of price, brand names and the attributes. With trade liberalization and implementation of the WTO-directed tariff and non-tariff rationalization, the Indian market is now infested with cheap imports of both consumer and intermediate products. They are now posing serious threat to the market share and profitability of the Indian industry.

Lastly and most importantly of the above two points, domestic as well as global financial surplus is now no longer geared to requirements of the Indian industry. Financial liberalization has de-linked the finance from industrial investment. To cope with the emerging challenges in the domestic and global market as well as to create a level playing field for the Indian industry it is of utmost necessity that technological development takes place in industry. But that warrants huge investment in import of capital good embodied new technology, new product innovation, marketing strategy and production processes. Without assistance from the financial system of the country this is neither possible nor feasible. Finance per se has no meaning unless it is canalization to the real economy. Real economic growth takes a back seat unless financial resources are made available and accessible. In fact, the above mentioned 
second challenge can be easily overcome if finance does not become a major hurdle for industrial expansion.

Indian manufacturing industries registered a steady growth rate since the beginning of economic reform, reached as high as 14 per cent in 1995-96. On an average industrial production stayed above 6 per cent per annum throughout the reform period. However, there is a widespread heterogeneity in the growth rate across the different industrial sectors. As far as sectoral source of growth rate is concerned the consumer goods (62.84\%) accounted for more than half of the overall growth. An attempt was made to develop the basic intermediate goods and machinery sectors. The contribution of capital goods declined from $13.28 \%$ in the pre reform period to $11.81 \%$ in the post reform period. However, the contribution of intermediate inputs increased from $23.87 \%$ to $35.65 \%$.

Table 12: Correlations coefficients of globalization and its components in India

\begin{tabular}{|c|c|c|c|c|c|c|c|c|}
\hline & Time & Economic & Personal & Technology & Political & $\mathrm{K}$ & KW & PC \\
\hline Time & 1.000 & & & & & & & \\
\hline Year & $\begin{array}{c}-0.745 \\
(0.055)\end{array}$ & 1.000 & & & & & & \\
\hline Economic & $\begin{array}{c}-0.322 \\
(0.481)\end{array}$ & $\begin{array}{c}0.588 \\
(0.165)\end{array}$ & 1.000 & & & & & \\
\hline Personal & $\begin{array}{c}0.943 \\
(0.001)\end{array}$ & $\begin{array}{c}-0.647 \\
(0.116)\end{array}$ & $\begin{array}{c}-0.388 \\
(0.390)\end{array}$ & 1.000 & & & & \\
\hline Technology & $\begin{array}{c}0.947 \\
(0.001)\end{array}$ & $\begin{array}{l}-0.647 \\
(0.116)\end{array}$ & $\begin{array}{c}-0.362 \\
(0.425)\end{array}$ & $\begin{array}{c}0.874 \\
(0.010)\end{array}$ & 1.000 & & & \\
\hline Political & $\begin{array}{c}0.810 \\
(0.027)\end{array}$ & $\begin{array}{l}-0.287 \\
(0.533)\end{array}$ & $\begin{array}{c}0.067 \\
(0.886)\end{array}$ & $\begin{array}{c}0.733 \\
(0.061)\end{array}$ & $\begin{array}{c}0.888 \\
(0.008)\end{array}$ & 1.000 & & \\
\hline GIndex (K) & $\begin{array}{c}0.650 \\
(0.114)\end{array}$ & $\begin{array}{c}-0.042 \\
(0.930)\end{array}$ & $\begin{array}{c}0.251 \\
(0.588)\end{array}$ & $\begin{array}{c}0.597 \\
(0.157)\end{array}$ & $\begin{array}{c}0.750 \\
(0.052)\end{array}$ & $\begin{array}{c}0.968 \\
(0.000)\end{array}$ & 1.000 & \\
\hline $\begin{array}{l}\text { GIndex } \\
\text { (KW) }\end{array}$ & $\begin{array}{c}0.921 \\
(0.003) \\
\end{array}$ & $\begin{array}{c}-0.531 \\
(0.220)\end{array}$ & $\begin{array}{l}-0.354 \\
(0.435)\end{array}$ & $\begin{array}{c}0.952 \\
(0.001)\end{array}$ & $\begin{array}{c}0.947 \\
(0.001) \\
\end{array}$ & $\begin{array}{c}0.865 \\
(0.012) \\
\end{array}$ & $\begin{array}{c}0.758 \\
(0.048)\end{array}$ & 1.000 \\
\hline
\end{tabular}

Table 12 reports the correlation coefficients of the different indices and their components for India. The numbers in the parentheses are respective correlation coefficients. The globalization process is increasing over time for each index, where principal component index recorded greater correlations followed by Kearney and weighted Kearney. The economic component is highly decreasing over time (-0.745). Personal component also recorded falling trend (-0.322), while technology (0.943) and political (0.947) components shows an increasing trend. It is surprising to note that technological components and economic components are negatively $(-0.116)$ correlated. This contradicts with the proposition that trade and foreign direct beings technology.

Table 13 gives information on the development of globalization index over time in India. It appear that despites its short period it can provide a partial picture of globalization covering the current time periods. Both unweighted and weighted globalization index showed a fluctuating trend, increased from 1995-1997. It declined sharply in 1998 due to fall in overall components except technological change. The index bounces back in 1999 propelled largely by better personal and political components. Once again it declined in 2000 due to overall fall in each of the components. 
Table 13: Development of globalization index in Indian over time

\begin{tabular}{ccccccccccc}
\hline Year & Eco & Eco(w) & Persl. & Persl(w) & Tech & Tech(w) & Political & GIndex & GInde(w) & Prin123 \\
\hline 1995 & 0.127 & 0.212 & 0.176 & 0.177 & 0.002 & 0.004 & 1.571 & 1.876 & 1.965 & -0.192 \\
1996 & 0.153 & 0.257 & 0.281 & 0.282 & 0.003 & 0.006 & 1.549 & 1.986 & 2.094 & -0.207 \\
1997 & 0.128 & 0.203 & 0.269 & 0.270 & 0.002 & 0.005 & 1.725 & 2.124 & 2.202 & -0.129 \\
1998 & 0.070 & 0.096 & 0.169 & 0.170 & 0.004 & 0.008 & 1.731 & 1.974 & 2.005 & -0.137 \\
1999 & 0.053 & 0.071 & 0.215 & 0.216 & 0.005 & 0.011 & 1.829 & 2.103 & 2.127 & -0.040 \\
2000 & 0.050 & 0.065 & 0.201 & 0.203 & 0.008 & 0.017 & 1.813 & 2.073 & 2.098 & 0.041 \\
2001 & 0.090 & 0.106 & 0.186 & 0.188 & 0.010 & 0.019 & 2.016 & 2.301 & 2.329 & 0.229 \\
Mean & 0.096 & 0.144 & 0.214 & 0.215 & 0.005 & 0.010 & 1.748 & 2.062 & 2.117 & -0.062 \\
\hline
\end{tabular}

In order to estimate the impact of globalization on the labor market in manufacturing sector we have collected data from Annual Survey of Industries, published by Central Statistical Organization. Industry level analysis is used a balanced panel of 22 two digit industries for the years 1994-95 to 2000-2001. The average size of employment in the manufacturing industries is 6.87 million while on an average each firm employs 52 workers. (See Table 14) Each worker received 30.37 thousand rupees per annum. The average output produced during these periods is 80.95 million rupees. As far as labor productivity in manufacturing is concerned each worker produces the value of output of 0.87 million rupees. ${ }^{12}$

Table 14: Summary statistics of the aggregate data of Indian manufacturing (19952001)

\begin{tabular}{lr}
\hline Variable definition & Mean \\
\hline Total manufacturing employment in million & 6.87 \\
Employment per factory & 51.67 \\
Annual wage/ worker (in thousand rupees) & 30.37 \\
Aggregate output (in million rupees) & 80.95 \\
Annual growth rate of industrial production & 7.71 \\
Output per worker (in million rupees) & 0.87 \\
\hline
\end{tabular}

Source: Annual Survey of Industries, 2000-01

In order to shed lights on the nature of relationships between the composite globalization indices and a number of key indicators from Indian manufacturing we employed a series of regression analysis. ${ }^{13}$ The results suggest that the low level of wages in India does not promote Indian globalization computed using the 13 indicators selected by the Kearney. Neither the level of globalization, weighted or unweighted, in a significant way affect the level of any of the four key indicators from Indian manufacturing including: wages, employment, output or net value added. Thus, the direction of causality can not be established. Such a linkage can neither be found in relation with only the economic component of globalization.

The entire variations in the four indicators are explained by industry specific effects. The adjusted R-squares are in the interval 0.92 to 0.97 . The lack of relationship

\footnotetext{
12 One Rupees was 0.022 US\$ in March 2005

${ }^{13}$ These results are not reported here. These can be obtained upon request.
} 
between globalization and these indicators might be explained by inadequate representation of globalization or the manufacturing lack of representation for the entire Indian economy. It should be noted that these 4 manufacturing indicators are both industry and time variant, while the globalization index is only variable over time. Wage is increasing, employment decreasing, output increasing, and net value added constant over time. In order to save spaces, we have not reported the results here. However, they can be obtained from the authors upon request.

\section{SUMMARY AND CONCLUSIONS}

Globalization is a complex phenomenon involving multidimensional components. The present study is an attempt to quantify the process of globalization using nonparametric Kearney and parametric principal component analysis. Countries are ranked on the basis of their level and development of globalization. Depending on the data availability the indices are composed of four major components: economic integration, personal contact, technology and political engagements. The development of the index components has also been constructed over time and across countries. Alternatively both weighted and unweighted versions of the two indices are also computed.

Globalization is a structure of interconnection involving redistribution of the national economy integrated in to a world economy with least impediments in the movement of goods and factors of production. The results show that not only internal and external conflicts seem to effectively reduce the globalization prospects for many developing countries but also sociopolitical environment hold back its growth and development. Of all components, political engagement is the biggest contributor. Not surprising because the elements of political component heavily biased towards few industrialize nations does not involve the common people to a big ways.

The low ranking position of the country is often associated with weak economic and technology factors which most certain developing countries are unable to address. The high ranking industrialized countries share similar patterns in various component distributions. The mean globalization by region shows that personal and technology factors play an important role in determining the ranking position of the regions. This breakdown of the index into major components offers the possibility to identify the sources of globalization and link these to economic policy measures to bring about desirable changes in national and international policies.

It is interesting to note that during the current phase of globalization least globalized countries emerge as best performer. Right now both China and India are the fastest growing economy but they are way behind as globalized of the developing countries. They are integrating their economy at a faster pace, clearly holds a lesson for many other developing countries. In India high population growth coupled with complex cultural geography and continuing geopolitical tension jeopardize the equitable development of globalization.

The performance of Indian economy is not attached to its globalization. Its performance depends on its policy implementation. The rate growth of the economy was high since 1991, after taking up economic reform. In a regression analysis we investigated the relationship between the composite globalization indices and a number of key indicators from Indian manufacturing. The result shows that globalization does not 
affect Indian manufacturing in any significant ways. The lack of relationship between globalization and these indicators can be explained by inadequate representation of globalization or the manufacturing lack of representation for the entire Indian economy.

Although the current version of the index quantifies the level of globalization well, it has certain limitations and the results should be interpreted with caution. We have pointed to a number of improvements to overcome several of the shortcomings. These are important issues in understanding how globalization functions and learning to use the generated information in policy formulation and development evaluations. The index is in its early stage of development but has identified several directions along which future advances can be made. 


\section{REFERENCE}

Addison, T. and A. Heshmati (2004): "The New Global Determinants of FDI Flows to Developing Countries: The Impacts of ICT and Democratization”, Research in Banking and Finance 4, 151-186.

Agénor, P. R. (2003). 'Does Globalization Hurt the Poor?’. Washington, DC: World Bank, Unpublished manuscript

Aghion, P. and J. G. Williamson (1998): “Growth, Inequality and Globalization: Theory, History and Policy”, Cambridge: Cambridge University Press.

Andersen, T. M., and T. T. Herbertsson (2003): “Measuring Globalization”, IZA Discussion Paper 2003: 817

Balakrishnan, P. (2003): “Globalisation, Growth and Justice”, Economic and Political Weekly, June 26

Baldwin, R. E. and P. Martin (1999): "Two Waves of Globalization: Superficial Similarities, Fundamental Differences" NBER Working Paper 6904

Bardhan, P. (2001): "Social Justice in Global Economy”, Economic and Political Weekly, February 3-10, 2001, Pgs 467-480

Barro, R. (2004): “Current protectionism and the benefits of free trade”, Journal of Policy Modeling, Vol. 26, pp. 507-512

Bata, M. and A. J. Bergesen (2002a): "Global Inequality: An Introduction (to Special Issue on Global Economy - Part I)”. Journal of World-System Research, 8 (1): 2-6.

Bata, M. and A. J. Bergesen (2002b): "Global Inequality: An Introduction (to Special Issue on Global Economy - Part II)”, Journal of World-System Research, 8 (2): 146-48.

Baylis, J. and S. Smith (2001): "The Globalization of World Politics - An Introduction to International Relations”, Oxford University Press.

Besley, T. and R. Burgess (1998): "Land Reform. Poverty Reduction and Growth: Evidence from India”, Development Economics Discussion Paper Series, 13, London School of Economics, The Suntory Centre

Bevan, D. L. and A. K. Fosu (2003): "Globalization: An Overview". Journal of African Economies, 12 (1): 1-13

Bhagwati, J. (2004): “Anti Globalization: Why?”, Journal of Policy Modeling, Vol. 26, pp. 239-463

Bolaky, B and C. Freund (2004): “Trade, Regulations, and Growth”, World Bank Working Papers.

Bordo, M. D., Eichengreen, B., and Irwin, D. A., (1999): "Is Globalization Today ReallyDifferent than Globalization a Hundred Years Ago?" NBER Working Paper 7195,June

Bowles, S. (2001): “A Future of Labour in the Global Economy”, TIPS Working Paper, 4-2001 
Collins, W. J. and Williamson J. G., (1999): "Capital Goods Prices, Global Capital Markets and Accumulation: 1870-1950" NBER Working Paper 7145.

Dollar, D and A. Kraay (2001): “Trade, Growth and Poverty”, World Bank, Mimeo

Dollar, D. and A. Kraay, (2002): “Institutions, Trade and Growth” Paper prepared for the Carnegie-Rochester Conference Series on Public Policy

Dollar, D., and P. Collier (2001): Globalization, Growth and Poverty: Building an inclusive World Economy. Oxford: Oxford University Press

Eckel, C. (2003): Labor Market Adjustments to Globalization: Unemployment versus Relative Wages'. North American Journal of Economics and Finance, 14 (2): 173-88

Ethier, W. J. (2002): “Globalization, Globalization: Trade, Technology, and Wages”. PIER Working Paper 031. Philadelphia: Penn Institute for Economic Research.

Ethier, W. J. (2002): “Globalization: Trade Technology and Wages”, PIER Working Paper 031, Penn Institute for Economic Research, Philadelphia.

Finance and Development (2002): “The Globalization of Finance”, March 2002, Volume 39, Number 1.

Ghose, A. K. (2003): “Jobs and Incomes in a Globalizing World”, International Labour Office, Geneva

Giffin, K. (2003): “Economic Globalization and Institutions of Global Governance”, Development and Change 34(5): 789-807

Gomory, R. E. and W. J. Baumol (2004): "Globalization: prospects, promise, and problems”, Journal of Policy Modeling, Vol. 26, pp. 425-438

Heshmati, A. (2003): "Measurement of a Multidimensional Globalization and its Impact on Inequality”, WIDER Discussion Paper 2003/69, Helsinki 2003/69, Helsinki: UNU-WIDER

Intriligator, M. D (2004): "Globalization of the world economy: potential benefits and costs and a net assessment”, Journal of Policy Modeling, Vol. 26, Issue 4, pp. 485-498

James, J. (2002): Technology, Globalization and Poverty, Cheltenham: Edward Elgar.

Kearney, A. T., Inc., and the Carnegie Endowment for International Peace (2002): 'Globalization's Last Hurrah?' Foreign Policy, January/February: 38-51.

Kearney, A. T., Inc., and the Carnegie Endowment for International Peace (2003): 'Measuring Globalization: Who's up, who's down?', Foreign Policy, January/February: 60-72.

Khan, A. R., and C. Riskin (2001): Inequality and Poverty in China in the Age of Globalization. Oxford: Oxford University Press.

Kindleberger, C., 1996, Manias, panics, and crashes, Wiley, New York.

Klein, L. (2004): “New Growth Centers in This Globalized Economy”, Journal of Policy Modeling, Vol. 26 
Krueger, Ann O. (1997): “Trade and Economic Development: How we Learn”, American Economic Review. 87(1): 1-22.

Lindert, P. H. and J. F. Williamson (2001): "Does globalization makes the world more unequal?”, NBER Working Paper 8228

Lockwood, B. (2001): "How Robust if the Foreign Policy/Kearney Index of globalization?”, CSGR Working Paper 79/01

Maddison, A. (2001): 'The World Economy: A Millennial Perspective. OECD Development Centre Studies. Paris: OECD.

Manning, S. (1999): 'Introduction (to Special Issue on Globalization)'. Journal of World-Systems Research, 5 (2): 137-41.

McCarthy, I and A. Anagnostou (2004): "The impact of outsourcing on the transaction costs and boundaries of manufacturing”, Int. J. Production Economics 88 (2004) 61-71

Miller, T. C. (2001): "Impact of Globalization on US Wage Inequality: Implications or Policy”, North American Journal of Economics and Finance, 12 (3): 219-42

Nagaraj, R. (2003): "Foreign direct investment in India 1990s: Trends and issues”, Economic and Political Weekly, 26 April, pp. 1701-1702

Nayyar D. and J. Court (2001): "Governing globalization: issues and institutions, WIDER Policy Brief 5, Helsinki: UNU/WIDER

Nayyar, D. (2001): “Globalization: What does it mean?” in Jome K. S. \& S. Nagaraj edited "Globalization versus Development”, Palgrave

Nayyar, D. (2002): "Cross border movement of people" in D. Nayyar (eds.) "Governing Globalization: Issues and Institutions”, Oxford University Press

O’Rourke, K. H. (2001): 'Globalization and Inequality: Historical Trends'. NBER Working Paper 8339. Cambridge, MA: National Bureau of Economic Research.

O'Rourke, K. H., and J. G. Williamson (2000): Globalization and History: The Evolution of a Nineteenth-Century Atlantic Economy. Cambridge, MA: MIT Press (see Review Essay by A. G. Frank (2002). Journal of World-Systems Research, 8 (2): 276-90).

O’Rourke, K. H., and J. G. Williamson (2000): Globalization and History: The Evolution of a Nineteenth-Century Atlantic Economy. Cambridge, MA: MIT Press (see Review Essay by A. G. Frank (2002). Journal of World-Systems Research, 8 (2): 276-90).

Obstfeld, M., Taylor A. M., (1998): "The Great Depression as a Watershed: International Capital Mobility over the Long Run" Published in Bordo, M. D., Goldin, C., and N. White, E. N., Eds. The Defining Moment: The Great Depression and the American Economy in the Twentieth Century. pp. 353-402 (Chicago: University of Chicago Press, 1998)

Robertson, R. (2004): “The Historical Context and Significance of Globalization”, Development and Change, 35 (3): 557-565 
Rodrik D., A. Subramanian, and F. Trebbi (2002): "Institutional Rule: The Primacy of Institutions over Geography and Integration in Economic Development" Mimeo, IMF.

Rodrik, D. (2004): ““Globalization and Growth — Looking in the Wrong Places”, Journal of Policy Modeling, Vol. 26

Rowntree, L et al (2000): “Diversity amid globalization: World religion, environment and development”, Prentice Hall

Sarma, A. (2002): "Prospects of trade and investment in India and China", International Studies, 39, 1, pp. 25-43

Stiglitz, J. (2004): “Globalization and growth in emerging markets”, Journal of Policy Modeling, Vol. 26, Issue 4, pp. 465-484

Stiglitz, Joseph. (2002): “Globalization and its discontents”, New York: W. W. Norton.

Tanzi (2004): “Globalization and the need for fiscal reform in developing countries”, Journal of Policy Modeling, 26 (2004) 525-542

Tausch, A., and P. Herrmann (2002): Globalization and European Integration. Huntington, NY: Nova Science.

Williamson, J. G. (2002): ‘Winners and Losers over Two Centuries of Globalization'. WIDER Annual Lecture 6. Helsinki: UNU-WIDER.

Winters, L. A. (2002): “Trade Policies for Poverty Alleviation”, in B. Hoekman, A. Matto and P. English (eds.), Trade, Development and the WTO, Washington, DC, World Bank

Woods, N. (1998): 'Editorial Introduction. Globalization: Definitions, Debates and Implications’. Oxford Development Studies, 26 (1): 5-13.

World Bank (2002): Globalisation, Growth and Poverty: Building an Inclusive World Economy, Policy Research Report, Oxford University Press, New York.

World Development Report (2003): "FDI Policies for Development: national and International Perspectives”. 


\section{APPENDIX}

Appendix A. Mean globalization (1995-2001) by country ranked by weighted Kearney globalization index (KW).

\begin{tabular}{|c|c|c|c|c|c|c|c|c|}
\hline Rank & Country & Economic & Personal & Technology & Political & $\mathrm{K}$ & KW & $\mathrm{PC}$ \\
\hline 1 & Ireland & 2.456 & 2.024 & 0.577 & 1.524 & 6.581 & 8.829 & 1.026 \\
\hline 2 & Singapore & 2.503 & 1.597 & 0.974 & 0.765 & 5.838 & 8.321 & 0.082 \\
\hline 3 & Switzerland & 1.450 & 1.975 & 1.015 & 1.717 & 6.158 & 8.238 & 1.021 \\
\hline 4 & Sweden & 1.430 & 0.970 & 1.372 & 2.244 & 6.016 & 8.125 & 1.210 \\
\hline 5 & Canada & 0.779 & 0.892 & 1.502 & 2.448 & 5.621 & 7.175 & 1.146 \\
\hline 6 & UK & 1.397 & 0.937 & 0.912 & 2.240 & 5.486 & 7.064 & 1.092 \\
\hline 7 & Netherlands & 1.742 & 1.019 & 0.840 & 1.570 & 5.172 & 7.032 & 0.754 \\
\hline 8 & Finland & 0.909 & 0.804 & 1.756 & 1.831 & 5.299 & 6.919 & 0.797 \\
\hline 9 & Denmark & 1.262 & 1.072 & 0.982 & 1.963 & 5.279 & 6.860 & 0.817 \\
\hline 10 & USA & 0.439 & 0.345 & 2.323 & 2.571 & 5.678 & 6.844 & 1.409 \\
\hline 11 & Norway & 0.778 & 0.781 & 1.645 & 1.708 & 4.912 & 6.645 & 0.604 \\
\hline 12 & Austria & 0.849 & 1.271 & 0.820 & 2.096 & 5.036 & 6.316 & 0.787 \\
\hline 13 & France & 0.655 & 0.814 & 0.347 & 2.550 & 4.367 & 5.227 & 0.971 \\
\hline 14 & New Zealand & 0.573 & 0.736 & 1.265 & 1.139 & 3.713 & 4.868 & 0.136 \\
\hline 15 & Germany & 0.664 & 0.648 & 0.588 & 1.956 & 3.855 & 4.837 & 0.610 \\
\hline 16 & Australia & 0.511 & 0.363 & 1.385 & 1.417 & 3.677 & 4.617 & 0.302 \\
\hline 17 & Portugal & 0.831 & 1.089 & 0.300 & 1.424 & 3.645 & 4.560 & 0.101 \\
\hline 18 & Czech & 0.797 & 1.278 & 0.254 & 1.440 & 3.769 & 4.361 & 0.180 \\
\hline 19 & Italy & 0.592 & 0.590 & 0.264 & 2.107 & 3.554 & 4.234 & 0.506 \\
\hline 20 & Malaysia & 1.097 & 0.737 & 0.200 & 1.297 & 3.331 & 3.917 & -0.237 \\
\hline 21 & Spain & 0.589 & 0.684 & 0.304 & 1.574 & 3.151 & 3.847 & 0.249 \\
\hline 22 & Hungary & 0.810 & 0.812 & 0.192 & 1.311 & 3.126 & 3.704 & -0.008 \\
\hline 23 & Israel & 0.516 & 1.078 & 0.541 & 0.771 & 2.905 & 3.670 & -0.392 \\
\hline 24 & Panama & 1.777 & 0.328 & 0.055 & 0.641 & 2.801 & 3.481 & -0.533 \\
\hline 25 & Poland & 0.356 & 0.633 & 0.145 & 1.896 & 3.030 & 3.385 & 0.177 \\
\hline 26 & Greece & 0.302 & 0.903 & 0.180 & 1.330 & 2.714 & 3.209 & -0.058 \\
\hline 27 & Japan & 0.278 & 0.117 & 0.622 & 1.533 & 2.550 & 3.168 & 0.202 \\
\hline 28 & Argentina & 0.412 & 0.103 & 0.078 & 1.999 & 2.592 & 2.974 & 0.250 \\
\hline 29 & Korean Republic & 0.437 & 0.269 & 0.424 & 1.107 & 2.236 & 2.874 & -0.299 \\
\hline 30 & Russian Federation & 0.333 & 0.110 & 0.038 & 2.204 & 2.685 & 2.860 & 0.226 \\
\hline 31 & Slovenia & 0.492 & 0.592 & 0.555 & 0.525 & 2.164 & 2.809 & -0.684 \\
\hline 32 & Croatia & 0.526 & 0.961 & 0.128 & 0.596 & 2.212 & 2.800 & -0.660 \\
\hline 33 & Chile & 0.674 & 0.199 & 0.152 & 1.130 & 2.155 & 2.768 & -0.210 \\
\hline 34 & Nigeria & 0.589 & 0.310 & 0.001 & 1.684 & 2.584 & 2.765 & -0.122 \\
\hline 35 & Egypt & 0.220 & 0.481 & 0.006 & 1.936 & 2.643 & 2.731 & 0.066 \\
\hline 36 & Slovak & 0.589 & 0.409 & 0.226 & 0.916 & 2.140 & 2.574 & -0.557 \\
\hline 37 & Botswana & 0.725 & 1.137 & 0.022 & 0.466 & 2.350 & 2.534 & -0.871 \\
\hline 38 & Tunisian & 0.379 & 0.532 & 0.014 & 1.282 & 2.206 & 2.365 & -0.331 \\
\hline 39 & Senegal & 0.350 & 0.549 & 0.005 & 1.318 & 2.221 & 2.344 & -0.375 \\
\hline 40 & Pakistan & 0.164 & 0.416 & 0.001 & 1.708 & 2.290 & 2.339 & -0.133 \\
\hline 41 & Kenya & 0.204 & 0.514 & 0.006 & 1.502 & 2.226 & 2.252 & -0.351 \\
\hline 42 & China & 0.337 & 0.047 & 0.014 & 1.617 & 2.015 & 2.245 & -0.095 \\
\hline 43 & Mexico & 0.433 & 0.250 & 0.048 & 1.140 & 1.872 & 2.189 & -0.251 \\
\hline 44 & Indonesia & 0.433 & 0.076 & 0.009 & 1.501 & 2.020 & 2.179 & -0.222 \\
\hline 45 & South Africa & 0.490 & 0.138 & 0.148 & 0.937 & 1.712 & 2.149 & -0.434 \\
\hline 46 & Venezuela & 0.398 & 0.103 & 0.050 & 1.316 & 1.868 & 2.138 & -0.188 \\
\hline 47 & Thailand & 0.614 & 0.143 & 0.046 & 1.056 & 1.859 & 2.126 & -0.472 \\
\hline 48 & Romania & 0.295 & 0.329 & 0.052 & 1.242 & 1.918 & 2.121 & -0.326 \\
\hline 49 & India & 0.096 & 0.214 & 0.005 & 1.748 & 2.062 & 2.117 & -0.062 \\
\hline 50 & Taiwan & 0.505 & 0.429 & 0.499 & 0.008 & 1.442 & 2.114 & -1.163 \\
\hline 51 & Philippi & 0.742 & 0.157 & 0.021 & 0.904 & 1.824 & 2.110 & -0.526 \\
\hline 52 & Bangladesh & 0.065 & 0.399 & 0.000 & 1.629 & 2.093 & 2.107 & -0.270 \\
\hline 53 & Turkey & 0.266 & 0.262 & 0.043 & 1.356 & 1.927 & 2.079 & -0.228 \\
\hline 54 & Brazil & 0.250 & 0.050 & 0.068 & 1.438 & 1.805 & 2.043 & -0.120 \\
\hline 55 & Morocco & 0.258 & 0.642 & 0.005 & 0.942 & 1.847 & 1.927 & -0.589 \\
\hline 56 & Sri Lanka & 0.370 & 0.614 & 0.007 & 0.747 & 1.737 & 1.856 & -0.747 \\
\hline
\end{tabular}




\begin{tabular}{lllllllll}
57 & Ukraine & 0.391 & 0.275 & 0.013 & 1.043 & 1.722 & 1.854 & -0.629 \\
58 & Saudi Arabia & 0.416 & 0.145 & 0.009 & 0.983 & 1.552 & 1.831 & -0.445 \\
59 & Uganda & 0.211 & 0.854 & 0.001 & 0.629 & 1.695 & 1.812 & -0.824 \\
60 & Peru & 0.312 & 0.165 & 0.091 & 0.934 & 1.502 & 1.790 & -0.424 \\
61 & Colombia & 0.315 & 0.169 & 0.036 & 0.970 & 1.491 & 1.759 & -0.402 \\
62 & Iran & 0.145 & 0.067 & 0.003 & 1.065 & 1.281 & 1.294 & -0.481 \\
\hline
\end{tabular}

Notes: Kearney unweighted (K), Kearney weighted (KW) and Principal Component (PC) globalization indices. 
Figure 1: Unweighted Kearney Globalization index (K) decomposed by components.

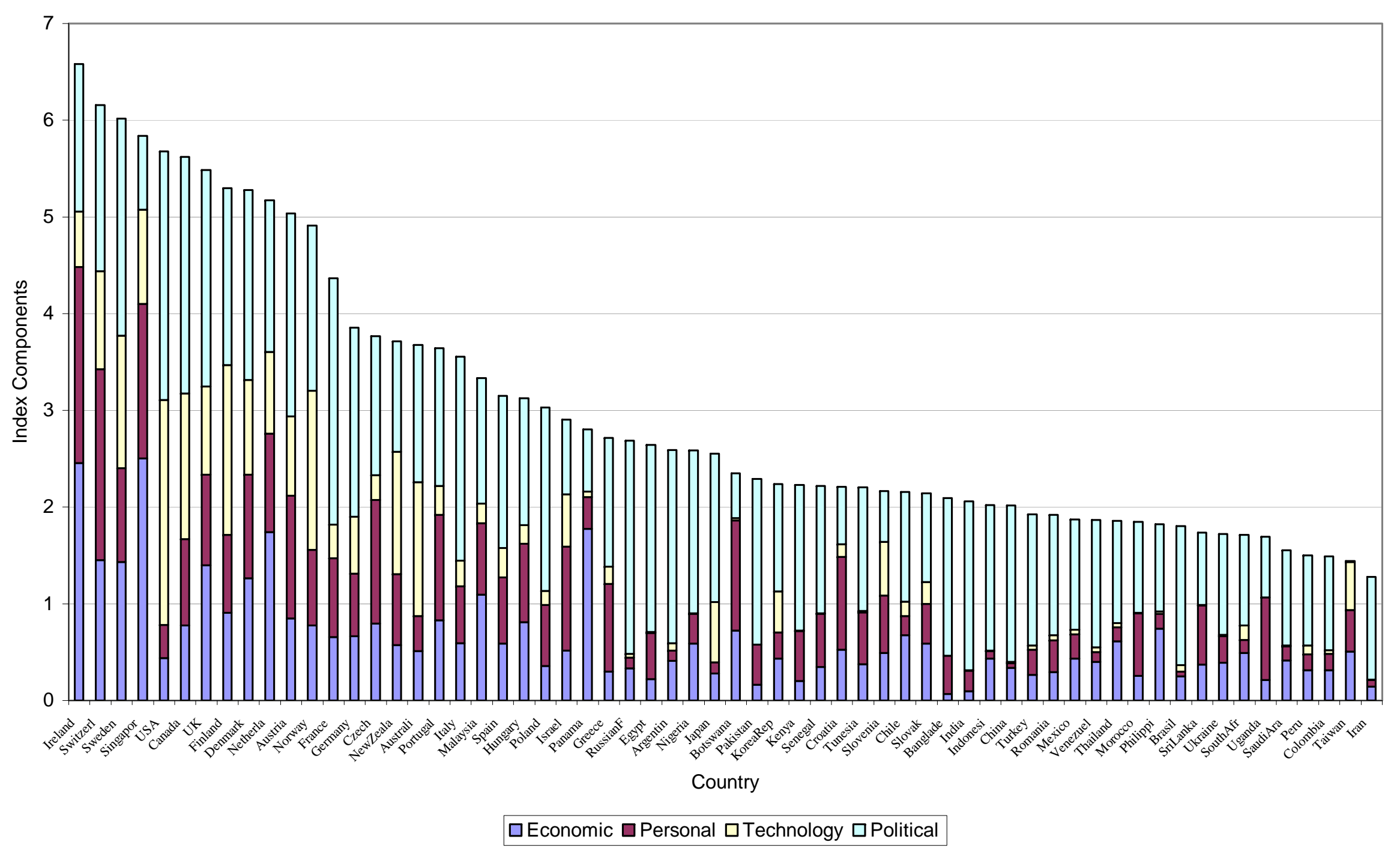


Figure 2: Kearney index by country (Ranked by 1998 position)

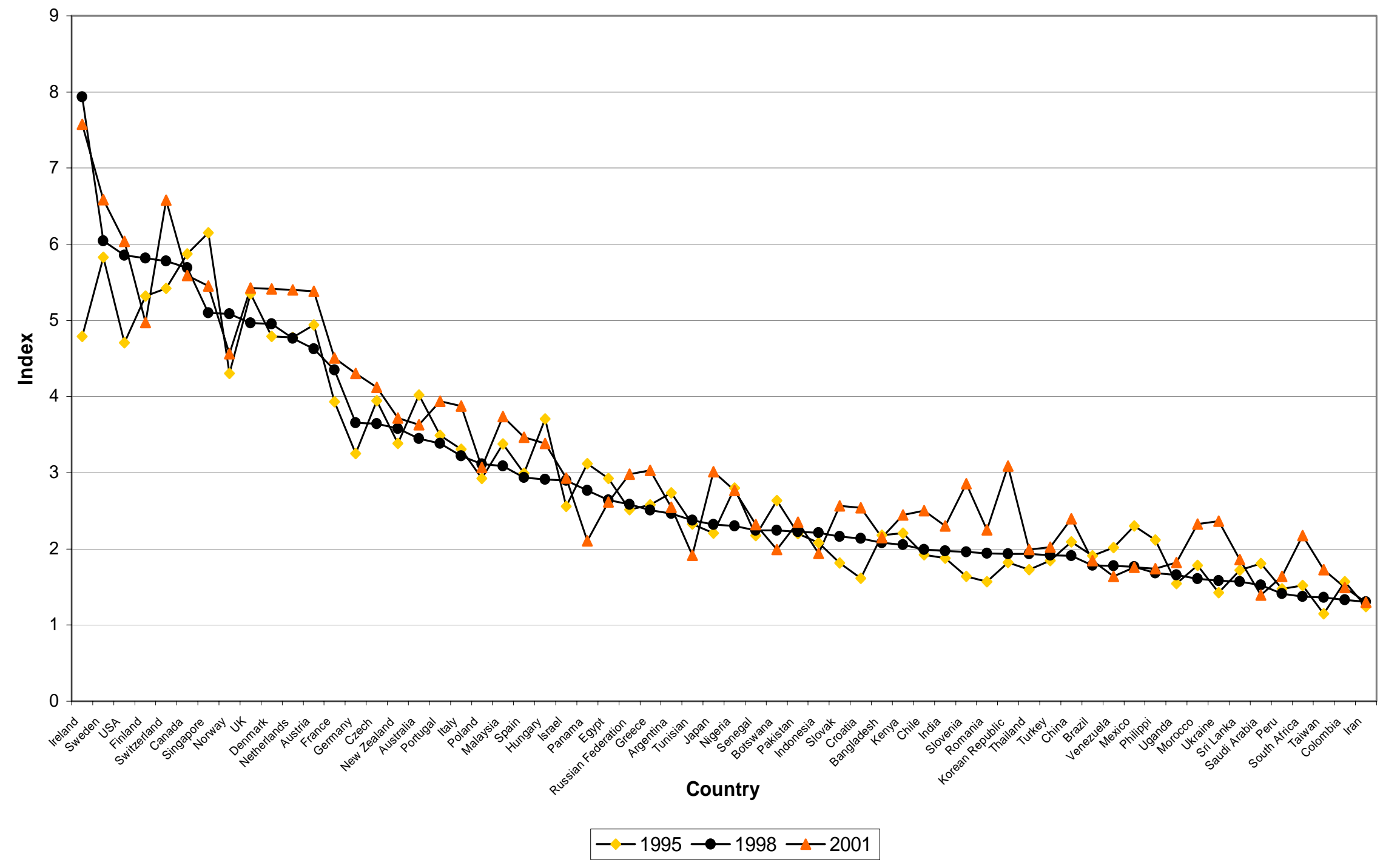

